\title{
قواعد المقاصد
}

\section{حقيقتها ومكانتها في التشريع}

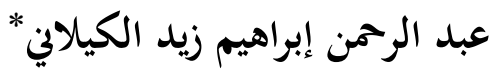

يتناول هذا البحث موضوعاً متخصصاً من موضوعات علم مقاصد الشريعة الاسلامية، هو قواعد المقاصد. ويهدف البحث إلى بيان مفهوم القاعدة المقصدية، وتمييزها من القاعدة الفقهية والقاعدة الأصولية، وتوضيح أهميتها وعلاقتها بكليات التشريع وجزئياته. وقد تركز اهتمام البحث على القواعد المقصدية التي ساقها الامام الشاطبي في كتابه الموافقات، ثم استدعاء الانتباه الى ضرورة استقراء المقاصد في جهود علماء الأمة الاخرين، وتفعيل هذه القواعد بالصور التطبيقية والوقائع العلمية. ذلك أنه منذ أنزل القرآن الكريم على رسول الله صلى الله عليه وسلم وآيات الكتاب العزيز تتعاقب على تأكيد ارتباط أحكام الشريعة الاسلامية الكلي منها والجزئي بالحكم والمصالح والمعاني التي تكفل سعادة الانسان في عاجله وآجله ودنياه وآخرته.

وتغدو هذه الحقيقة واضحة مستمرة بتتبع كثيراً من النصوص التشريعية، التي تبين الصلة الوثقى بين الأحكام والحكم، وتوضح أن هذه الأحكام ما هي إلا وسائل لتحقيق مقاصد عليا، تتجسد مصالح حيوية واقعية في حال إقامتها والامتثال بها. ومن ذلك على سبيل المثال والاجمال قوله تعالى في بيانه لحكم الصيام في رمضان وحكمته هو كتب عليكم الصيام كما كتب على الذين من قبلكم لعلكم تتقون (البقرة: 183).

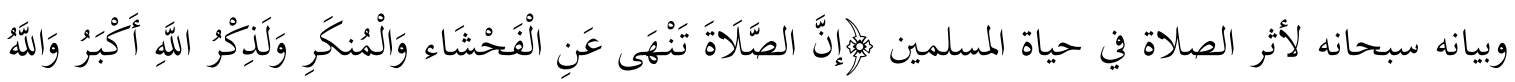
يَعْلَمُ مَا تَصْنَعُونهُمه (العنكبوت :45). وإظهار للغاية المتوخاة من الأمر ببذل الوسع في إعداد القوة

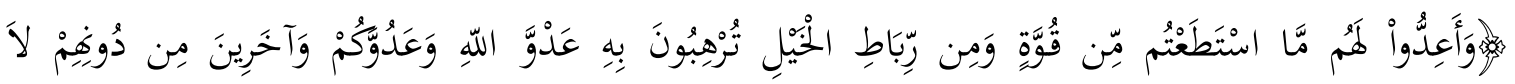

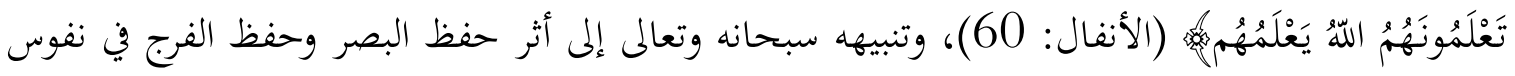

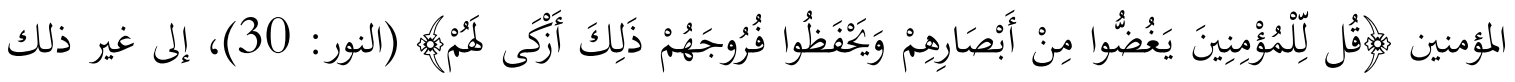


من الآيات الاتي تبين من ارتباط أحكام الشرعية بقلنون الغاية وتنفي من جهة أخرى العبثية في التشريع. ومثل هذا السنن العام الذي مضى عليه الشارع في تشريعه واستقر حقيقة ثابتة لا تقبل النقض، يعكس معقولية الشريعة الاسلامية ويدعو المجتهدين إى تبين هذه المقاصد المعقولة، كوها تمثّل الأساس الذي قام عليه البناء التشريعي كله.

ومن هنا ظهر علم المقاصد وتتابعت الجهود العلمية وتنامت الدراسات المستقلة، التي بذلت في بحث مقاصد الشريعة الاسلامية واستقرائها. ولا ينكر أحد قيمة الجهود المتواصلة في إظهار هذا العلم ووضع ضوابطه شروطه، ابتداءً بالإمام الجويني في كتابه "البرهان"، وتلميذه الإمام الغزالي في كتابيه "المستصفى" و"شفء الغليل"، والإمام العز بن عبد السلام في كتابه "قواعد الأحكام"، والإمام القرافي في كتابه "الفروق". ومروراً بمن جاء بعدهم من مثل الإمام الآمدي في كتابه "الإحكام"، والإمام ابن تيميه في كتبه المعروفة ووعلى رأسها كتاب "الفتاوى"، وتلميذه ابن القيم في كتابه "إعلام الموقعين"، وانتهاءً بالإمام الشاطبي شيخ علم المقاصد الذي تناول هذا الموضوع باستفاضةٍ وعمق، وأسلوبٍ أصوليّ فذ، لا أجد غيره ممن تقدّمه قد نسج على منواله، بعد أن تزود بكل ما كتبه السابقون، واستفاد منها، ولا أعدو الحقيقة إذا قلت: إن ما قدمه السابقون في علم المقاصد هو بمثابة مقدمة بالنسبة إلى ما بحثه الامام الشاطبي في هذا العلم.

فضلا عن الجهود المعاصرة التي قدمها العلماء المعاصرون في موضوع علم مقاصد الشريعة الاسلامية من مثل: كتاب "مقاصد الشريعة الاسلامية" للشيخ الطاهر بن عاشور، و"المقاصد العامة للشريعة الاسلامية" للدكتور يوسف حامد العالم، و"مقاصد الشريعة الاسلامية ومكارمها" للأستاذ علال الفاسي، و"نظرية المقاصد عند الامام الشاطبي" للدكتور أحمد الريسون، و"نظرية المقاصد عند الامام الطاهر بن عاشور" للأستاذ اسماعيل الحسني، إلى غير ذلك من الدراسات والأبحاث المقدمة خدمة لعلم المقاصد، وبياناً

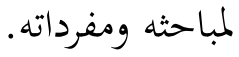

وإن من الموضوعات والمباحث التي تنضوي تحت لواء (علم مقاصد الشريعة الاسلامية) البحث في كيفية ضبط هذا العلم الواسع عن طريق قواعد محددة مضبوطة، حتى لا يكون هذا العلم فضفاضاً فيدخل فيه ما ليس منه، أو يخرج منه ما هو في صميم مدلولاته، ويمكن تسمية خذا البحث (بقواعد المقاصد). 
ورحم الله الامام الزركشي الذي نبه إلى أخمية ضبط العلوم بقواعد محددة فقال:" إن ضبط الأمور المنتشرة المتعددة في القوانين المتحدة أوعى لحفظها وأدعى لضبطها". وإن مما يسجل للإمام الشاطبي من مظاهر الابداع والتجديد التي أضافها إلى علم المقاصد، ما قدمه من جهد عظيم في مجال تقعيد المقاصد، حيث زخر كتابه "الموافقات" في العديد من تلك الكليات الجامعة لمعانٍ تشريعية عامة تشكل كل منها معلماً أساسياً

$$
\text { من المعالم التي إلتفت إليها الشارع الحكيم في تشريعه. }
$$

وهذه القواعد أشار إليها الدكتور أحمد الريسوني حفظه الله في كتابه القيم "نظرية المقاصد عند لإمام الثاطبي" حيث سرد ما يزيد عن خمسين قاعدة مقصدية ساقها الامام الشاطبي في كتابه "الموافقات" على أن حقيقة القاعدة المقصدية، وتحديد المراد بها ما زال خوضوعاً بحاجةٍ إلى دراسةِ وبحثٍ ونظٍٍ لا سيما إذا علمنا أن هناك مصطلحات قريبةٍ وذات صلةٍ هذذا المصطلح من مثل (القاعدة الفقهية) و(القاعدة الأصولية).

ويقع في سياق البحث في القاعدة المقصدية البحث في أهميتها ومكانتها في مقام الاستلال والاجتهاد، إضافة إلى ضرورة تحديد المحاور التي يمكن أن تكون منطلقاً لأبحاثٍ أخرى في سياق البحث في القاعدة المقصدية. من أجل هذا كله كان هذا البحث مركزاً على ما ذكره الامام الشاطبيّ في كتابه "الموافقات"، وداعياً إلى ضرورة بذل المزيد من الجها في سبيل ضبط هذا العلم وبيان أبرز معالمه وأسسه.

\section{حقيقة القاعدة المقصدية:}

يمكن تعريف القاعدة المقصدية بأها:

(قضية كلية يعبر بها عن معنيً عام مستفاد من أدلة الشريعة المختلفة ابتهت ارادة الشارع إلى إقامته

$$
\text { مت خلال ما شرع من أحكام).1 }
$$

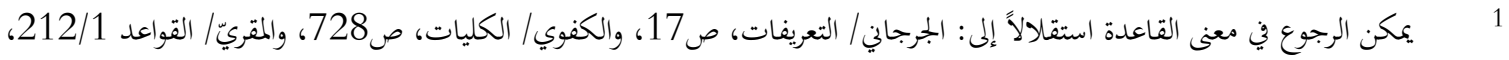

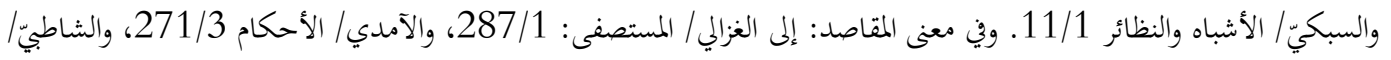


وقبل أن أشرع في بيان هذا التعريف وتحليله، أود أن أمثل لبعض القواعد المقصدية لبيان حقيقتها وذلك من خلال ما ساقه الامام الشاطبيّ:

$$
\text { 1. الشارع لا يقصد التكليف بالشاق والإعنات فيه. } 2
$$

2. لا نزاع فيأن الشارع قاصدٌّ إلى التكيف بما يلزم من كلفة ومشقةٍ ما، ولكنه لا يقصد نفس المشقة،

$$
\text { بل يقصد ما في ذلك من المصالح العائدة على المكلف. } 3
$$

3. إذا كانت المشقة أمراً خارجاً عن المعتاد بحيث يحصل للمكلف بها فساد ديني أو دنيوي، فمقصود

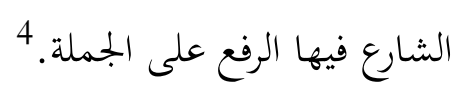

فهذه قواعد مقصدية يتعلق موضوعها في رفع الحرج في الشريعة الاسلامية، وهي على سبيل المثال لا

وهناك قواعد مقصدية تتعلق بالمصلحة والمفسدة من مثل:

$$
\text { - وضع الشرائع إنما هو لمصالح العباد في العاجل والآجل معاً. } 5
$$

- المفسدة إذا كانت هي الغالبة بالنظر إلى المصلحة في حكم الاعتياد، فرفعها هو المقصود شرعاً،

$$
\text { ولأجله وقع النهي.6 - 2 - 2 }
$$

- المفهوم من وضع الشارع أن الطاعة أو المعصية تعظم بحسب عظم المصلحة أو المفسدة الناشئة

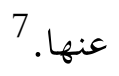

- ترك إعتبار المصالح في الأوامر الصادرة عن الشرع يعد مخالفة لقصده في تشريعها. 8

$$
\begin{aligned}
& 2 \\
& \text { 3 } \\
& 4 \\
& \text { 6 } \\
& 6 \\
& \text { 7 } 6
\end{aligned}
$$


- تتفاوت درجات الأمر حسب تفاوت درجات المأمو، ضرورياً كان أو حاجياً أو تحسينياً.

- العمل بالظواهر على تتبع وتغال، بعيد عن مقصود الشارع، كما أن إهمالها إسراف أيضاً. 10

$$
\text { - المصالح والمفاسد راجعة إلى خطاب الشارع. } 11
$$

- الأصل في العبادات التوقف دون الالتفات إلى النعاني، وأصل العادات الإلتفات إلى المعاني.12

هذه بعض القواعد المقصدية التي استعرضها الامام الشاطبي بالشرح والبيان والتفصيل والتأصيل. ومقام البحث هنا بيان حقيقة هذه القاعة، وأستعرض ذلك من خلال ما ذكرته من تعريفها، وضمن النقاط التالية:

أولاً: تتسم هذه القواعد بالكلية، أي أها ليست مختصة بباب دون باب، أو حال دون حال، ولا زمان دون زمان، ولا بشخصٍ دون شخص، فهي من الكلية والاتساع بحيث تشمل جميع الأبواب والأشخاص والأقوال والأزمان وهذا واضعٌ جليّ في القواعد التي استعرصها، حيث إن الصفة الكلية ظاهرة

$$
\text { بينة فيها. }
$$

ثانياً: هذه القاعدة الكلية تعبر عن معنى عام قصده الشارع والتفت اليه، وعرفنا قصد الشارع له من خلال تصفح كثير من الجزئيات والأدلة التي هضت بذاك المعنى العام. فالقاعدة المقصدية "النظر في المآل

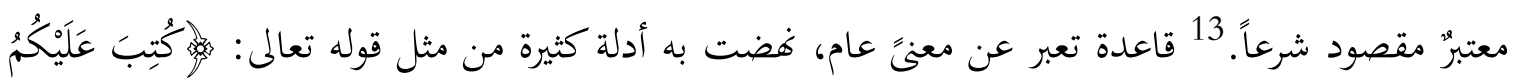

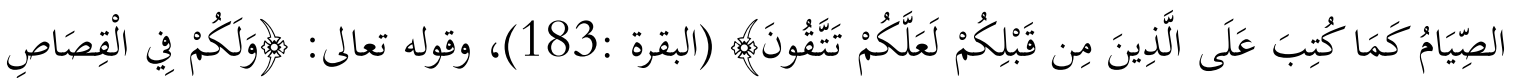

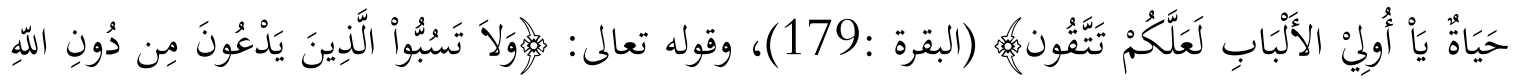

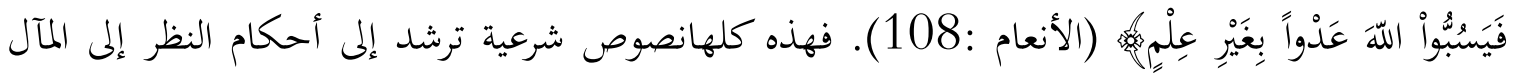
عند بيان الحكم، مما يشير إلى اعتبار ذلك المآل وتوجه القصد إليه.

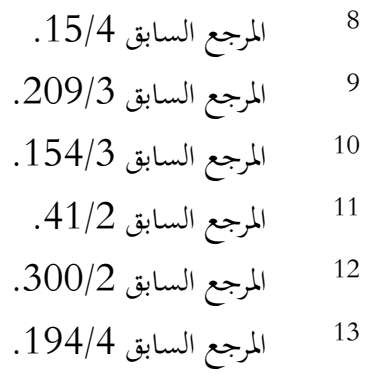


ثالثاً: ووصفي لهذه المعاني بأها عامة، لإخراج المعاني الخاصة والمقاصد الجزئية التي ترتبط بالأحكام الجزئية، إذ إن هذه المعاني الخاصة ليست هي موضوع القاعدة المقصدية، ومثال هذه المعاني الخاصة: المعاني المقصودة من النكاح، إذ هو مشروع للتناسل، والسكن والتزوج، والتعاون على النصالح الدنيوية والأخروية، من الاستمتاع بالحلال، والنظر إلى ما خلق الله من المحاسن في النساء، والتجمل بمال المرأة أو قيامها عليه أو على أولاده منها. 14 فهذه كلها مقاصد جزئية لا تتعرض القاعدة المقاصدية لأفا لا تقرب المعاني الحاصة، وإنما موضوعها المعاني العامة الكلية التي تتفرع عنها معانٍ خاصة. ولقد عرفنا عموم هذه المعنى الذي عبرت عنه القاعدة المقصدية من خلال تصفح الكثير من الجزئيات والأدلة الشرعية التي تقرر هذا المعنى وتفضي إليه. والإمام الشاطبي يبين في كتابه "الموافقات" أن العموم إذا ثبت فلا يلزم أن يثبت من جهة الصيغ العامة فَحَسب، بل له طريقان:

أحدهما: الصيغ العامة إذا وردت، وهو المشهور من كلام أهل الأصول. والثاني: استقراء مواقع المعنى، حتى يحصل منه في الذهن أمرٌ كليّ عام، فيجري مجرى العموم المستفاد من الصيغ. 15 ومقصود الشاطبي بعموم الصيغ: الصيغ اللفظية التي بين الأصوليون إفادتا للاستغراق والشمول، بحيث تتناول جميع الأفراد التي

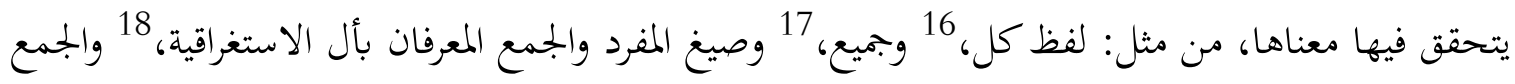
والمفرد المضافان إلى معرفة، 19 إلى غير ذلك من صيغ العموم.ومثالها في صيغة (كل) يثبت الموت لجميع النفوس من غير استثناء أو تخصيص، فلا يخرج أحد من النهاية والأجل المختوم، فهذا هو النوع الأول من العموم، وهو عموم الصيغ. أما النوع الثاني فهو عموم المعاني، وهذه القواعد المقصدية هي من النوع الثاني من العموم، فإذا كان العموم الأول هو عموم لفظي فإن الثاني هو عموم معنوي، ومقصود الشاطبيّ بمواقع

$$
\begin{aligned}
& 14 \\
& 15 \text { المرجع السابق 298/3. }
\end{aligned}
$$

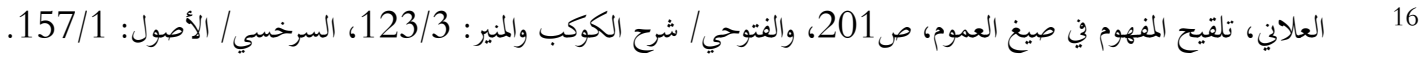

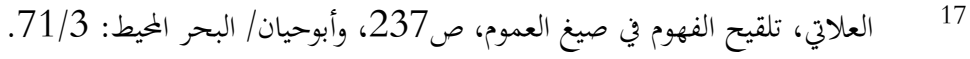

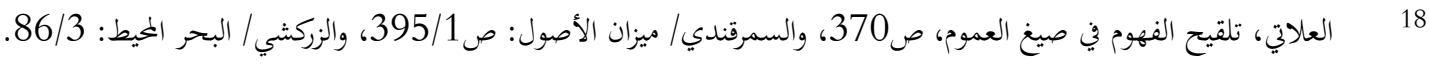

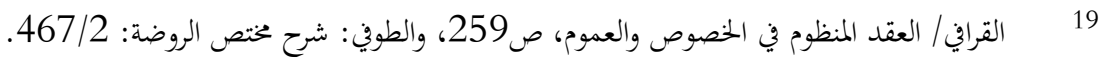


المعنى: متعلقات الأحكام من الوقائع الجزئية المتعددة التي اختلفت في موضوعاتا، واتفقت في أصل معناها، بحيث أفضت إلى هذا المعنى العام المقصود شرعاً، ويبّن الامام الشاطبيّ طريقة استفادة هذه المعاني المقصدية في معرض تفصيله للضروريات والحاجيات والتحسينات: فيقول: (ودليل ذلك - أي اعتبار هذه المراتب استقراء الشريعة- والنظر في أدلتها الكلية والجزئية،وما انطوت عليه هذه الأمور العامة،على حد الاستقراء المعنوي الذي لا يثبت بدليل خاص، بل بأدلة مضاف بعضها إلى بعض، مختلفة الأغراض بحيث ينظم من بجموعها أمرُ واحد، بتجتمع عليه تلك الأدلة). وقولي هذا الأصل المعنوي: أنه اتجهت ارادة الشارع إلى إقامته عن طريق أحكامه، بيان أن الأحكام هي وسائل إقامة هذه المقاصد، وتحقيقها في الوجود الانساني، واقعياً وتطبيقياً، حتى لا تبقى محلقة في سماء التنظير.

يظهر لنا هذا الارتباط بين الحكم الشرعي وبين المعنى الذي تتضمنه القاعدة المقصدية، وكيف أن الحكم هو وسيلة للحفاظ على هذا المعنى الذي توجهت إرادة الشارع إليه، أقول يظهر هذا الارتباط في ما ساقه الامام الشاطبي من قواعد مقصدية، وأردفها بأحكام تفيد تحقيق معاني هذه القواعد، من ذلك مثلاً: القاعدة المقصدية التي نص عليها الامام الشاطبيّ: (قصد الشارع من المكلف أن يكون قصده في العمل موافقاً لقصده في التشريع، وألا يقصد خلاف ما قصد). ${ }^{21}$ فهذه القاعدة المقصدية تعبر عن معنى مفاده: وجوب التطابق بين قصد المكلف في أثناء امتثاله للتكليف والقيام به، وبين قصد الشارع من أصل التكليف لذاك الفعل. وحتى يضمن تحقيق هذا المعنى وامتثاله لئلا يناقض المكلف قصد الشارع من تشريعه، بين الإمام الشاطبيّ، الجزاء الذي يترتب في حال المناقضة الاختلاف بين قصد الشارع وقصد المكلف، فقال :( كل من ابتغى في تكاليف الشريعة غير ما شرعت له فقد ناقض الشريعة، وكا من ناقضها فعمله في المناقضة باطل، فمن ابتغى في التكاليف ما لم تشرع له فعملع باطل).22

\begin{tabular}{|c|c|}
\hline الموافقات 51/1. & 20 \\
\hline المرجع السابق 332/2. & 21 \\
\hline المرجع السابق 233/2. & \\
\hline
\end{tabular}


فالإمام الشاطبي حتى يكفل المحافظة على المعنى العام، الذي يقتضي التوافق بين قصد الشارع من جهة، وقصد المكلف من جهةٍ أخرى، يكشف عن هذا الحكم الشرعيّ العام المترتب في حال الاختلال المقصود بين هذين المقصدين - أقصد قصد الشارع وقصد المكلف - وبين الشاطبيّ أن الحكم في ذلك، هو بطلان كل تصرف يستعمله المكلف يناقض فيه قصد الشارع وحكمته من أصل تشريع هذا التصرف المأذون

فالمعنى العام الذي تعبر عنه القاعدة المقصدية يحتاج إلى حكم عام ليؤيد إقامة هذا المعنى وحقيقة وعدم الاخلال به. ولا تخل في القواعد المقصدية - التي جعلتها موضوعاً لهذا البحث - القواعد التي تحدد كيفية معرفة المقاصد الشرعية، أو مسالك الوقوف على المقاصد مثل:

1- الأمر بالفعل يستلزم قصد الشارع إلى وقوع ذلك الفعل، والنهي يستلزم القصد إلى منع وقوع

2- وقاعدة: إذا سكت الشارع عن أمرٍ مع وجود داعي الكلام فيه، دل سكوته على قصده إلى

الوقوف عند ما حدّ وشرع.

3- وقاعدة: وضع الأسباب يستلزم قصد الواضع إلى المسببات. 25

فهذه القواعد تتعلق بكيفية تحديد مقصد الشارع، وهو موضوع عني به الشاطبيّ وعقد له مبحثاً مستقلاً، 26 وسبب عدم دخولها في القواعد المقصدية أها لا تعبر عن معنى عام توجهت إرادة الشارع إلى ولى إقامته، وإنما هي قواعد تظهر كيفية الوقوف على تلك المعاني وليس على المعاني ذاها، فبات الفقرق بينها وبين القواعد التي بصدد بحثها كالفرق بين الوسيلة وغايتها.

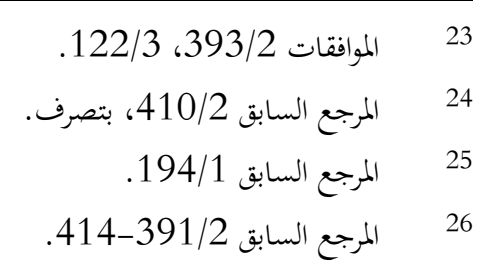


كما يستثنى من هذه القواعد التي لا تتعلق بمقاصد الشريعة، ولا بالمعاني الكلية التي توجهت إرادة الشارع لإقامتها عن طريق أحكامها. ذلك أن الامام الشاطبيّ قد ساق قواعد أخرى غير القواعد المقصدية، من مثل: فعله صلى الله عليه وسلم دليلٌ على مطلق الأذن فيه، ما لم يدل دليل على غيره. 27 - العمومات جارية على العموم الاستعمالي الشرعيّ. - المتشابه واقع في الشرعيات إلا أنه قليل. - بيان الصحابة حجة فيما أجمعوا عليه.

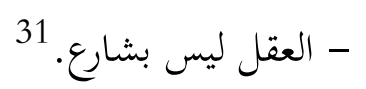
فهذه القواعد الأصولية وغيرها كثير لا تعبر عن المعاني العامة التي التفت إليها الشارع في تشريعه، وإنما هي قواعد أصولية استدلالية تتعلق بالأدلة التفصيلية، الكتاب والسنة والاجماع والقياس، أو تتعلق بالألفاظ، كالعام والخاص والمطلق والمقيد، أو يكون موضوعها الحكم الشرعي، كالواجب والمندوب والمباح والحرام والمكرو.

\section{مكانة القاعدة المقصدية في التشريع:}

وأعنى بمكانة القاعة: ارتبة أو المنزلة التي تتبوؤها القاعدة المقصدية في التشريع، وظهر لي من خلال البحث في كتاب الموافقات أ هذه المرتبة أو المكانة التي تتجلى من خلال محورين اثنين: علاقة هذه القواعد الكلية بجزئيات الشريعة وفروعها، وإمكانية ورود النسخ على هذه الكلية.

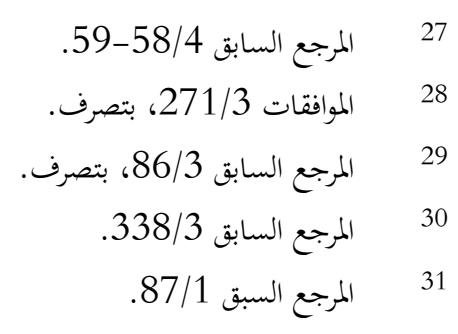




\section{المحور الأول: علاقة هذه القواعد الكلية بجزئيات الشريعة وفروعها:}

يقرر الإمام الشاطبيّ أن هذه الكليات لا بد من اعتبارها عند دراسة الجزئيات، فلا يصح فصل الجزئي عن كليّه، لأن الجزئيات محكومة بالكليات، ويصرح بذلك فيقول: فمن الواجب اعتبار تلك الجزئيات في هذه الكليات عند اجراء الأدلة الخاصة من الكتاب والسنة والاجماع والقياس، فمحال أن تكون الجزئيات مستغنية عن كلياها، فمن أخذ بنص في جزئي معرضاً عن كليّة فقد أخطأ، وكما أن من أخذ بالجزئي معرضاً عن كلية فقد أخطأ، كذلك من أخد بالكلي معرضاً عن جزئية). ولما كانت القاعدة المقصدية من كليات الشريعة الأساسية كان لا بد من اعتبارها عند دراسة الجزئيات، والنظر فيها لاستفادة الأحكام. ذلك أن الفقيه إذا اقتصر في فقهه على جزئيات الشريعة دون أي التفات أو عناية بالكليات، وهي محور الجزئيات وقطب رحاها، فالا ريب أنه سيخرج بأحكام تكون مجافية لحكمة الشريعة وروح التشريع. ويثبت صحة هذه الدعوة استعراض بعض الفتاوى والاجتهادات التي لم تراع فيها هذه الكليات المقاصدية منها: ما ورد عن بعض الحنفية من أن القتل بالمثقل كالحجر أو الخشبة الكبيرة لا توجب القصاص على القاتل، ولا يُعَدّ فعلاً عمداً حتى ولو كان عدواناً، إذ العمد عندهم هو الضرب بسلاح كالسيف أو الرمح، أو ما جرى بجرى السلاح، كامحدد من الخشب أو النار، لأن العمد هو القصد، ولا يوقف عليه إلا بدليلها وهو استعمال الآلة القاتلة. 33

وأيدوا قولمم هذا ببعض الأحاديث منها:34 "كل شيئ خطأ إلا السيف، وكل خطأٍ أرش"، 35 "لا قود إلا بالسيف".

وبين السرخسي كيفية الاستلال بهذه الأحاديث، فقال في توجيهه لأحاديث "لا قود إلا بالسيف": (فيكون دليلاً لأبي حنيفة رمه الله أن القود لا يجب إلا بالسلاح، حتى إذا قيل إنسانُ بحجرٍ كبير، أو خسبة

$$
\begin{aligned}
& 32
\end{aligned}
$$

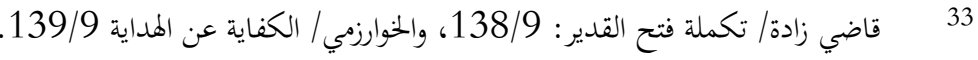

$$
\begin{aligned}
& 34 \\
& 35 \\
& 36 \text { ابن ماجه/ السنن (2667). }
\end{aligned}
$$


عظيمة، لم يلزمه القصاص في قول أبي حنيفة. وفي قول أبي يوسف ومحمد والشافعيّ - رحمم الله - يلزمه القصاص).

فالقول بهذا الرأي على إطلاقه قد يؤدي إلى التصادم مع بعض القواعد المقاصدية الكلية. وبيان ذلك: أن من الكليات المقررة في الشريعة وجوب النظر في المآل، والالتفات إلى نتائج الأفعال، وهو ما عبر عنه الشاطبيّ بقوله: (والنظر في المآلي معتبرٌ مقصوداً شرعاً).

ومن القواعد المقررة أيضاً: وجوب حفظ النفس الانسانية بدفع المفاسد عنها، وإن القول بأن القتل بالمثل لا يعد عمداً، ولا يوجب القصاص، رغم توفر عنصر العدوان فيه سيؤدي إلى المآل الممنوع وسيفتح باب القتل على مصراعيه، حيث يقدم القاتل على جريمته بالمثل الذي يقتل غالباً، عالماً أنه لن يطالبه القصاص، في هذا فتحُ لباب إهدار النفس الانسانية التي تُعد المحافظة عليها من أعظم المقاصد، بل من الضروريات التي لا تقوم الحياة إلا بها.

لقد أشار الإمام الجويني إلى هذا المعنى، في معرض بيانه للمال المتوقع قي حال القول بعدم القصاص بالمثل، حيث قال: (فكذلك نعلم أنهّ لو ترك - أي القصاص- في المثقل لوقع الهرج، ولأادى الامر إلى كل من أراد قتل إنسان، فإنه يعدل عن المحدد إلى المثقل، دفعاً للقصاص عن نفسه إذ ليس في المثقل زيادة مؤونة ليست في المحدد، بل كلن المثقل أسهل من المحدد، ولا يجوز في كل شرع تراعى فيه مصالح الخلقق، عدم وجوب القصاص بالمثل).

ونلاحظ فب البيان للإمام الجويني، ما يستند إليه من كليات عامة تمثل عند التحقيق قواعد مقصدية، فقوله: " ولأدى الأمر إلى كل من أراد قتل إنسان فإنه يعدل عن المحدد إلى المثقل". إظهار منه لمفسدة المآل

$$
\text { 38 } 37 \text { وقد مكم الزيلعي بضعف هذين الحديثين، الزيلعي/ نصب الراية 341/4 والسرخسي/ المبسوط 194/26. }
$$

39 هذا ما نقله الرازي في (الخصول 162/5، عن الإمام الجويني وقد وردت عبارات للإمام الجويني في "البرهان" تؤدي إلى هذا المعنى

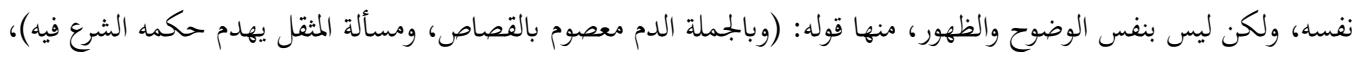

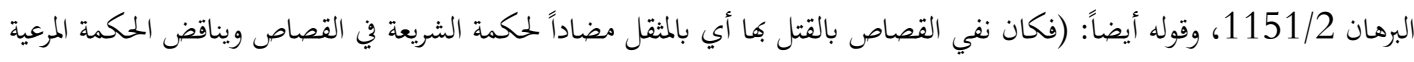

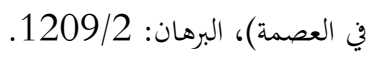


المتوقع، الذي يتمثل في تعريض النفس الإنسانية للإهدار، على حين تسعى الشريعة إلى حفظهاوصيانتها، فكان هذا القول مناقضاً لقصد الشارع بذلك. ومنشأ الاختلال:

عدم دراسة الجزئيات من خلال كلياتها التي تحكم بها، وتوجّه فهمها. ومن هنا كان رأي الشافعية والحنابلة، أن القتل بالمثل عادة، أو كان في مقتل، أو في مرض، أو حر أو برد شديدين، أو توالي الضربات، هو القتل الذي يُعَد عمداً ويوجب القصاص. 40 أما المالكية فقد ذهبوا إلى أبعد من ذلك، عملاً بقاعدة الاحتياط، وسداً لذرائع الفساد بقدر الامكان، وصوناً للنفس الانسانية من أي خطر أو مفسدة، حيث قالوا إن القتل بالمثل يُعد قتلاً عمداً، سواء كان هذا المثل مما يقتل غالباً أم لا، ما دام الفعل عدواناً، نظراً منهم

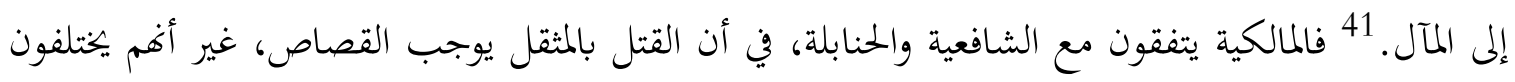
معهم في عدم اشتراط كون المثقل مما يقتل غالباً، بل يكفي عندهم أن يكون أداة أدت إلى القتل ما دام هذا

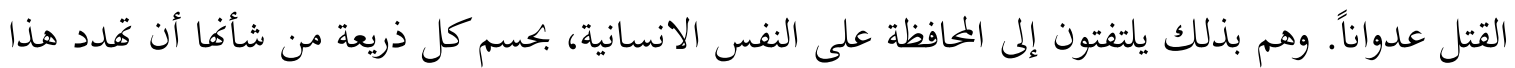
المقصد الضروري.

فظهر بذلك ما للكليات من أثر في توجيه الجزئيات. ولقد عبر عم هذا المعنى العظيم الإمام الشاطبيّ بقوله: "فمن الواجب اعتبار تلك الجزئيات بهذه الكليات، عند إجراء الأدلة الخاصة من الكتاب والسنة والإجماع والقياس".

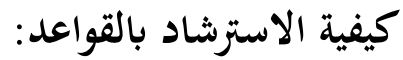

$$
\text { 40 }
$$

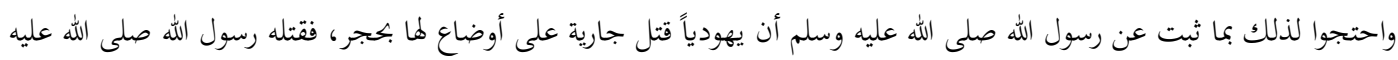

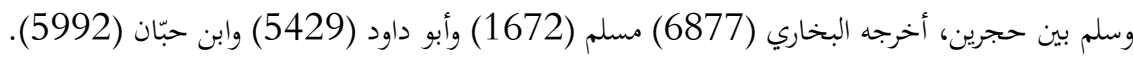

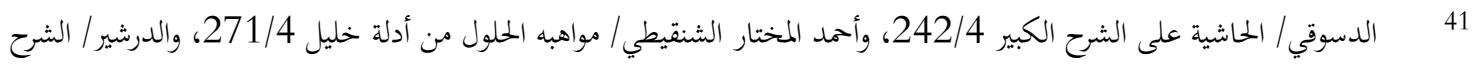

الصغير 23/4.

الموافقات 8/3. 
وإن المتتبع لاجتهاد الأئمة السابقين في فروع المسائل والجزئيات، يجد استرشادهم بالمقاصد العامة، لتوجيه الأدلة على حسبها، بحيث لا تتناقض البتة مع مقرراها ولا مع مقتضياتا. وهذه مجموعة من المسائل تظهر الاسترشاد بالقواعد الكلية للكشف عن الحكم، وعدم الاكتفاء بالجزئيات والأدلة الخاصة فقط.

أولا: وردت نصوص ترشد إلى عظمة النفس الانسانية تتحقق في كل من قال لا إله إلا الله، جاء ذلك في الحديث: "أمرتُ لأن أقاتل الناس حتى يشهدوا ألا إله إلا الله، فإذا قالوا عصموا مني دمائهم وأموالهم إلا بحقّها، وحساكم على الله".43 وعلى ذلك فإن من نطق بالشهادتين تحققت عصمة دمه وماله، إلا إذا فعل ما يوجب رفعها. ونجد الفقهاء ينظرون إلى هذه النصوص من خلال كليات الشريعة ظهر هذا واضحاً في توبة الزنديق؛ هيث ذهب الحنفية، 44 والمالكية، 45 والإمام الغزالي من الشافعية46 وفي رواية عند الحنابلة 47 إلى أن الزنديق الذي يظهر الإسلام ويتستر بالكفر فيتوب بعد أن يرفع أمره إلى الحاكم لا تقبل توبته ويقتل.

وكان مسند العلماء في ذلك: أن تظاهر الزنديق بالاسلام، من حيث النطق الصوري بكلمة التوحيد، قد يكون وسيلة إلى المساس بأصل حفظ الدين وهو أظهر مقاصد الشريعة وأهمها شأناً، وفي هذا الفساد العظيم ما فيه، وفسّر الامام الغزالي الحديث الوارد في تحقيق عصمة النفس بمجرد النطق بالشهادتين تقسيراً لا يؤدي إلى الإخلال بأصل حفظ الدين، فقال: "ووجه قتله - يعني الزنديق - أن المعلوم من الشرع أن الكافر مقتول، ونحن نكف عن قتلت لتوبته، والمعنى لتوبته تركه الدين الباطل، واليهودي والنصراني وكل مِلّي يعتقد النطق بكلمة الشهادة كفراً في دينه وتركاً له، فإذا أسلم فموجب دينه أنه تارك لدينه، وموجب دين الزنديق عند شهادته أنه يستعمل دينه، فهذا وجه التأويل والنظر". 48

$$
\begin{aligned}
& 43 \text { 4 أخرجه من حديث أبي هريرة: البخاري (1399)، ومسلم (21) وأبوداود (1556)، والنسائي 145/5، والترمذي (2609)، وابن } \\
& \text { ماجة (3927). } \\
& \text { ابن عابدين/ الحاشية: 296/3، والدسوقي/ الحاشية على الشرح الكبير: 306/4، والغزالي/ شفاء الغليل ص221، 227، والبهوتي/كشاف } \\
& \text { القناع: 177/6. } \\
& \text { 4 } 45 \\
& 46 \\
& \text { 177/6 البهوتي/كشاف القناع } 48
\end{aligned}
$$

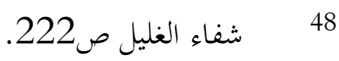


لقد فسر الإمام الغزالي الحديث على وجه لا يعرض الكلي إلا الإهدار أو النقض، فحمل الحديث الذي يفيد عصمة دم من يقول لا إله إلا الله، حمله على أهل الملل الذين يتركون دينهم حقيقة، وهذا ما لا لا يتحقق في الزنديق الذي يتستر بالشهادة، للاستمرار على انحرافه ودينه.

ولذلك ينبه الإمام الغزالي إلى هذا الملحظ في موضع آخر فيقول: "وإنما كلمة الشهادة تسقط القتل في اليهود والنصارى، لأفم يعتقدون ترك دينهم بالنطق بكلمة الشهادة، والزنديق يرى التقية عين الزندقة، فهذا لو قضينا به، فحاصله استعمال مصلحة في تخصيص عموم، وذلك لا ينكره أحد". 49

ورد الإمام القرطبي على الذين يحتجون بعدم قتل الرسول صلى الله عليه وسلم للمنافقين في زمانه، رغم تحقق معنى الزندقة فيهم، فقال: "فإن الله كان حفظ أصحاب نبيه - صلى الله عليه وسلم - بكونه ثبتهم أن يفسدهم المنافقون، أو يفسدوا دينهم، فلم يكن ضرر في بقائهم بين أظهرهم، وليس كذلك اليوم، لأننا لا نأمن من الزنادقة أن يفسدوا عامتنا وجهِّلنا". 50

هذا كله يدلنا على المنهج التوفيقي بين الكليات والجزئيات في التطبيق، بكيث أن الفقهاء لاحظوا أن الجزئي لا بد أن يسير دائماً في ركب الكلي لا ينقضه، أو يؤدي إلى إهداره، وا، الجزئيات لا بد أن تفسر دائماً على نهو تكون متوافقة مع الكليات.

ثانياً: يتجلى الاسترشاد بالقواعد المقصدية أيضاً عند النظر في الجزئيات، في توجيه العلماء في مسألة تضميت الصناع، حيث نجد أن عمادهم في ذلك بعض القواعد المقصدية القطعية، التي تضافرت على النهوض بها كليات الشريعة وجزئياتا.

إن القاعدة العامة: أن الأمين لا يضمن ما في يده من مال تسلمه من غيره لإصلاحه، إذا هلك أو تلف بدون تعمد منه، أو تقصير في حفظه، وعلى من ادعى تقصير الأمين أو تعديه، أن يقيم البيّنة على ذلك. ورغم ذلك أفنى كثير من علماء الصحابة بضمان الصناع، إذا ادعوا هلاك ما تسلموه من أمتعة غيرهم لاصلاحها، ما لم يقيموا البيّنة على أن ما هلك أو تلف بأيديهم، لم يكن بسبب تعمد من جانبهم أو

50 $\quad$ ت المستصفى 398/2.


تقصير. 51 ودليلهم في ذلك بينه الامام الباجي فيقول: "ما أدركت العلماء إلا وهم يضمنون الصناع، قال القاضي أبو محمد، لأن ذلك تتعلق به مصلحة، ونظر للصناع وأرباب السلع، وفي تركه ذريعة إلى إتلاف الأموال، ذلك أن بالناس ضرورة إلى الصناع، لأنه ليس كل أحد يحسن أن يخيط ثوبه، أو يقصره، أو يطرزه، أو يصبغه، فلو قلنا: القول قول الصناع في ضياع الأموال، لتسرعوا إلى دعوى ذلك، وللحق أرباب السلع ضرر لأفّم بين أمرين: إما أن يدفعوا إليهم المتابع فلا يأمن فيهم ما ذكرنا، وإما ألا يدفعون فيضربهم. ودليلنا من جهة المعنى، أنه قبض العين في مصلحة نفسه، من غير استحقاق للأخذ بعقد متقدم، فلم يقبل قوله في تلفها كالرهن والعارية.

إن هذا التحليل المقصدي يظهر لنا مقام القواعد المقصدية في استفادة الحكم وتوجيه الأدلة، وإن النظر العميق في التوجيه السابق سيرشدنا إلى أن تضمين الصناع يستند على عدة قواعد مقصدية وهي: 1- الموازنة بين المصلحة العامة والخاصة، إذ أن من المقرر أن الشارع يقصد إلى تقديم المصلحة العامة على الخاصة عند التعارض.53 2- النظر في المآل من حيث التفاته إلى الضرر الذي سيلحق بأرباب السلع، حيث يدّعي الصناع هلاكها من غير بيّنة أو دليل، فيؤول ذلك إلى الأموال وفي ذلك خخالفة لإحدى القواعد التشريعية المقررة. 3- مبدأ رفع الحرج، حيث إن امتناع أرباب السلع عند دفع سلعهم إلى الصناع خشية أن يدّعوا تلفها من غير بيّنة ولا إثبات، سيدفع الناس إلى عدم دفع السلع إلى الصناع، وفي هذا حرج بيّن وإضرار ظاهر بهم، وهو ما نبّه إليه الباجي بقوله: "أو لا يدفعون فيضر بهم".

هذه الأدلة التي هي في حقيقتها قواعد مقصدية يعبر كل منها عن معنى تشريعي عام، كانت حرية بأن توجه رأي الفقهاء القائلين بتضمين الصناع، وأن يلتفتوا إلى هذه القواعد المقررة، كأسس يبنون عليها

$$
\begin{aligned}
& 51 \text { ابن قدامة/ المغني 106/6، ابن حزم/ المحلى 202/8، البيهقي/ السنن 122/6. } \\
& 52
\end{aligned}
$$

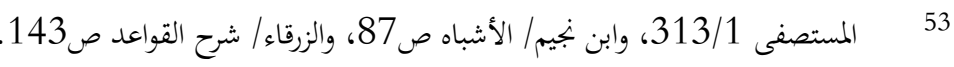


اجتهادهم، ويكشفون على هداها عن أحكام الشريعة في الوقائع والمستجدات، ولا يكتفون بالأدلة الجزئية وحدها للكشف عن الحكم الشرعي.

ثالثًا: ومن هذه الاجتهادات التي يلحظ فيها مراعاة الكليات عند دراسة الجزئيات، ما نص عليه الامام العز بن عبد السلام، من أنه لو رأى الصائم في رمضان غريقاً لا يتمكن من إنقاذه إلا بالفطر فإنه يفطر وينقذه. 54 ويعلل ذلك فيقول: "وهذا من باب الجمع بين المصالح، لأن في النفوس حقاً لله عز وجل، وحقاً لصاحب النفس، فقدم ذلك على فوات أداء الصوم دون أصله". 55 فالامام العز ينظر لإلى المسألة نظرة كلية يستند فيها على ما تقرره من مبادئ وأصول، تتضمن ابتناء الشريعة على أساس المصالح، وأن المصلحة تكون أكثر تأكداً وتحققاً في حال إفطار الصائم وإنقاذ الغريق، وأن المفسدة التي تنجم في حال بقاء الصائم على صيامه وتركه للغريق، أعظم من مفسدة الإفطار وفوات الصوم. وهذه النظرة الكلية ووزن الأمر بميزان الأغلب من المصلحة والمفسدة هو الذي أملى هذا الحكم الذي بيّه العز، وهي نظرة تعتمد مقاصد الشريعة كما هو ظاهر وواضح.

رابعًا: ومن هذه الاجتهادات أيضاً ما نص عليه الامام الجويني 56 والغزالي 57 والشاطبي 58، من أنه عجز بيت المال عن الوفاء بالتزاماته، وارتفعت الحاجات، وكانت الدولة بحاجة إلى تكثير الجنود لسد الثغور وحماية الملك المتسع في الأقطار، فإن للإمام إذا كان عدلاً أن يوظف على الأغنياء ما يراه كافيًا لهم في الحال، وله أن يفرض الضرائب لتكفي حاجات الدولة وتفي بالتزاماتما.

وهو نظر كلي للمسألة راعى فيه الفقهاء مقاصد الشريعة، إذ أن الإمتناع عن فرض مثل هذه الضرائب، سيعرّض الدولة الإسلامية للخطر، ويهدد مقصد الدين والنفس والمال بالفساد والفناء، وهذا ما عبّر عنه الغزالي بقوله: "إن لم يفعل الإمام ذلك تبدد الجند وانحل النظام وبطلت الشوكة، وسقطت أمة

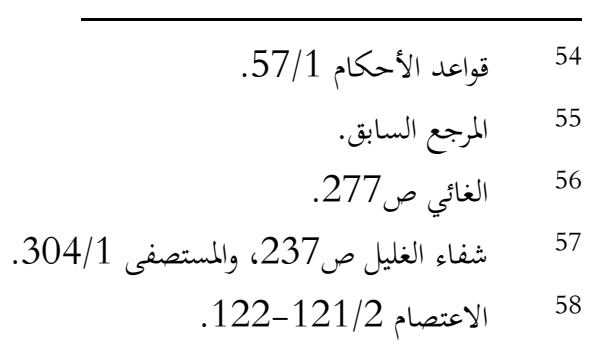


الإسلام، وتعرّضت ديارنا لهجوم الكفار واستيلائهم، ولو ترك الأمر دربه للرماح، وهدفاً للنبال ويثور بين الخلق من التغالب والتواثب، ما تضع بها الأموال، وتعطل معها النفوس وقتتك فيها الحرم". 59 إلى أن قال: "وهذا مما يعلم من كلي مقصود الشرع في حماية الدين والدنيا قبل أن نلتفت إلى الشواهد المعينة من أصول الشرع".

وظاهرٌ من هذا الاستدلال والتأييد للحكم، الإستناد إلى مقاصد الشريعة من حفظ الدين الذي يتم بجفظ سيادة الدولة التي تحرسه وتقوم على نشره، وحفظ النفس بهفظ الأمة التي تتعرّض بنفاذ خزائن الدولة لخطر الإصطلام ${ }^{61}$ والإجتثاث من قبل أعدائها، وحفظ المال الذي يتعرّض للإنهاب والإستلاب في حال غياب السلطة القوية القادرة على توفير الأمن وإقامته. ثم إن الإمام الغزالي يصرّح بالإستناد في ذلك إلى مقاصد الشريعة فيقول: "وهذا مما يعلم قطعاً في مقصود الشرع".

فهذه الأمثلة وغيرها كثير تكشف عن المنهج الذي كان يترسمه الأئمة المجتهدون في فقهرم وإجتهادهم. وحري بالمتهدين في عصرنا هذا، أن يترسموا ذات المنهج وألا تعزل النصوص الجزئية عن كلياتا العامة، فتفهم فهماً مبتوراً يؤدي إلى الإخلال بتلك الكليات.

الخور الثاني: هذه القواعد لا تقبل النسخ ولا النقض:

وكما أن هذه القواعد لا تنقض بآحاد الجزئيات، فكذلك هي من المكانة والقوة والرسوخ والإحكام

$$
\text { بحيث لا يمكن أن يرد عليها نسخ. }
$$

يقول الإمام الشاطبي في معرض بيانه لمكانة القواعد المتعلقة بالضروريات والحاجيات والتحسينات: (القواعد الكلية من الضروريات والحاجيات والتحسينات، لم يقع فيها نسخ، وإنا وقع النسخ في أمور جزئية، 
بدليل الإستقراء، فإن كان ما يعود بالحفظ على الأمور الحمسة ثابت، وأن فرض نسخ في بعض جزئياها، فذلك لا يكون لإلا بوحه آخر من الحفظ).

والإمام الشاطبي وإن كان قد خص بالذكر قواعد الضروريات والحاجيات والتحسينات، مبيناً أنها غير قابلة للنسخ، فهذا لا يعني أن عدم النسخ متعلق فقط بخصوص هذه المراتب الثلاث، وإنما يشمل أيضاً كل كليات الشريعة التي تؤكد حفظ هذه المراتب وتعمقها في الوجود والواقع. وهذا ما ألح إليه بقوله السابق: (إن كل ما يعمد بالحفظ على الأمر الخمسة ثابت). كذلك يقول في موقع آخر: (النسخ ال يكون في الكليات وقوعاً، وإن أمكن عقلاً)، 63 وعلى ذلك فإن جميع كليات الشريعة لا تقبل النسخ. ولما كانت القواعد المقصدية هي من ضمن هذه الكليات، وجي أ نيشملها هذا الحكم كذلك.

وبناءً عليه فإنه لا يتصور شرعاً أن يقع النسخ في أي قاعدة من القواعد المقصدية مثل: (المصلحة إذا كانت هي الغالبة عن مناظرتا بالنفسدة في حكم الاعتياد، فهي المقصود شرعاً، ولتحصيلها وقع الطلب على العباد)، 64 أو (قصد الشارع من المكلف أن يكون قصده من العمل موافقاً لقصده في التسريع). 65 أو (من مقصود الشارع في الأعمال دوام المكلف عليها). 66

ومرد إحكام هذه الكليات - ومن ضمنها قواعد المقاصد كما بينت - أها تتصل بمعاٍٍ أبدية لا يمكن أن تتعرض للنسخ أو الإلغاء، من مثل: إقامة العدل، والأمر بالبر، والنهي عن الفحشاء والمنكر، ودفع الظلم عن الناس، والحفاظ على النفس الإنسانية من الإزهاق وصون أعراض الناس وأموالهم وعقولمم من الخطر أو التفريط أو العدوان، إلى غير ذلك من الكليات الشرعية (التي تتصل بمعاٍٍ أبدية دلّت بتحارب الأمم على ضرورةا الحيوية لكل جيل، والنزول عند مقتضياتحا لأهما مقومات الحياة الإنسانية الفاضلة). 67

\begin{tabular}{|c|c|}
\hline الموافقات/ الشاطبي 117/3. & 62 \\
\hline المرجع السابق 104/3. & 63 \\
\hline المرجع السابق 26/2-27. & 64 \\
\hline المرجع السابق 231/2. & 65 \\
\hline المرجع السابق 242/2. & 66 \\
\hline
\end{tabular}


لذلك يقول الإمام الشاطبي منبّهاً إلى منشأ إحكام هذه القواعد وعدم إمكانية ورود النسخ عليها: (أجمعت الأمة، بل سائر الملل على حفظ هذه الأصول الخمسة)، 68 (وهكذا يقتضي في الحاجيات

والتحسينات).

ولا شك أن إجماع الأمة بل الأمم على وجوب مراعاة هذه الأصول المقصدية، راجع إلى ضرورتها في

حياتا، بحيث لا تستقيم الحياة الإنسانية إلا بها؛ ولهذا تُعد في التشريع الإسلامي من النظام التشرعي العام الذي لا بجوز مخالفته بأي حالٍ من الأحوال أو الإتفاق على مخالفته.

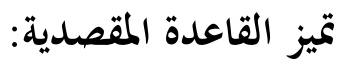

هذا وللقاعدة المقصدية تميز واستقلال عن غيرها من المصطلحات القريبة من مثل: القاعدة الفقهية والقاعدة الأصولية، يرشد إلى ذلك المقارنة بين طبيعة القاعدة المقصدية من جهة، وطبيعة القاعدة الأصولية والفقهية من جهة أخرى. - م.

\section{الفرق بين القاعدة المقصدية والقاعدة الفقهية:}

تعرف القاعدة الفقهية بأها (حكم شرعي في قضية أغلبية يتعرف منها أحكام ما دخل تحتها).70 وفي هذا المعنى تتفق والقاعدة المقصدية من حيث ما تتضمنه كلتا القاعدتين من معنى العموم والكلية، فضلاً عن أهما يتفقان في الغية النهائية، وهي تيسير الوقوف على حكم الشارع وابتغاه، على أن هذا الوفق بين القاعدتين تقف أمامه جملة من الفروق أجملها في القضايا التالية:

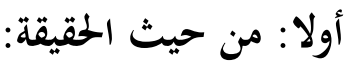

فحقيقة القاعدة المقصدية تختلف عن حقيقة القاعدة الفقهية، وبيان ذلك: أن القاعدة الفقهية بيانٌ لكم شرعي كلي، تتفرع عنه كثير من الأحكام الجزئية التي يتحقق فيها مناط ذاك الكلّي العام.

$$
\begin{aligned}
& 68 \\
& 69 \\
& 7070
\end{aligned}
$$


أما القاعدة المقصديّة فهي ليست بياناً لحكم شرعيّ تتفرع عنه أحكام جزئية من مسائل فرعية، وإنّا حين بيانُ للحكمة التي توخاها الشارع من أصل تشريع الحكم، وفرق بين الحكم والحكمة، فإذا كانت القاعدة الفقهية تعبيراً عن الحكم الكلي، فإن القاعدة المقصدية تعبير عن الحكمة والغاية، وعلى سبيل المثال: القاعدة الفقهية المقررة المشقة بتحلب التيسير)71 تقرر حكماً كلياً مفاده أن الجهد غير المعاد يكون سبباً للتسهيل على المكلف، لكنها لا تعبر عن غاية هذا الحكم الكلي وحكمته، في حين نجد القواعد المقصدية التي ساقها الإمام الشاطبي، زاخرة بييان غاية التيسير على المكلف، نجد هذا واضحاً جلياً في القواعد المقصدية التي جلاّها الإمام الشاطبي في معرض بيانه للمشقة، ومن ذلك مثلاً: (إن مقصود الشارع من مشروعية الرخص، الرفق بالمكلف من تحمل المشاق) الحرج مرفوع لسببين: الأول: خوف الضرر، أو الملل، أو أو بغض الطاعة أو كراهيتها.

\section{الثاني: خوف تعطيل الأعمال الأخرى والتقصير فيها. 72}

وهكذا نجد الإمام الشاطبي يغوص في الأحكام الشرعية، لاستنباط حكمتها وغايتها، ولا يكتفي بما قرره الفقهاء من أحكام كلية أو جزئية، بل يضيف إليها ويربطها بمقصدها لتكون أدعى إلى التطبيق والإمتثال من قبل المكلف.

\section{ثانياً: من حيث الحجيّة والمكانة: - من}

والمحور الثاني الذي يظهر لنا الفرق بين القاعدة المقصدية والقاعدة الفقهية فإن النصوص قد تضافرت على أنه لا يجوز الاستناد إلى ما تقتضيه القاعدة الفقهية فقط، كدليل يستنبط منه الحكم، أو لحكم يفتي به الفقيه، ولذلك يقول الحموي: (إنه لا يجوز بما لا تقتضيه القواعد والضوابط، لأها ليست كلية بل أغلبية). 73

$$
\begin{aligned}
& 71 \text { 7 الزركشي/ المنور من القواعد: 173/3، والسبكي/ الأشباه والنظائر 48/1، والسيوطي/ الأشباه والنظائر ص76 وابن نجيم/ الأشباه } \\
& \text { والنظائر ص75. } \\
& 72 \text { 7341/1 } 73 \text { الموافقات } \\
& 73
\end{aligned}
$$


وفي شرح بجلة الأحكام العدلية، تصريح بذلك حيث يقول علي حيدر في شرحه للقواعد الفقهية التي تصدرت مواد المجلة: (فحكام الشرع ما لم يقفوا على نقل صريح، لا يحكمون بمجرد الاستناد إلى واحد من هذه القواعد). فظهر بذلك التفاوت بين القاعدة الفقهية من جهة والقاعدة المقصدية من جهة أخرى، من حيث المرتبة والاعتبار وإمكانية الاستدلال بها كدليل مستقل. على أنه تخرج من ذلك القواعد الفقهية التي تستند إلى نص خاص ورد في خصوص المسألة كقاعدة (الخراج بالضمان) حيث وردت في سياق حديث لرسول الله صلى الله عليه وسلم. وقاعدة (جناية العجماء جبار) 76 حيث وردت في معرض قول للرسول صلى الله عليه وسلم (العجماء جرحها جبار). 77 فمثل هذه القواعد لا ينطبق عليها الفرق السابق، نظراً لقوة مسندها والذي يتمثل في الحديث الشريف المصرح بالقاعدة نصاً. ثالثاً: من حيث الأهمية والاعتبار: والأمر الثالث الذي يظهر لنا الفرق بين القاعدة الفقهية، والقاعدة المقصدية، الأهمية والمكانة، فمرتبة القاعدة المقصدية أعلى من مرتبة القاعدة الفقهية، وسبب ذلك راجع إلى الموضوع الذي تناولته كل من القاعدتين، فلما كانت القاعدة الفقهية تعبر عن حكم شرعي كلي، والقاعدة المقصدية تعبر عن غاية تشريعية عامة، وكانت الأحكام هي وسائل إقامة المقاصد وطريقة تحقيقها، ترتب على ذلك: أن تكون القاعدة المقصدية، مقدمة على القاعدة الفقهية؛ لأن الغايات مقدمة على الوسائل، والقاعدة الفقهية تعبر عادة عن

$$
\begin{aligned}
& 74
\end{aligned}
$$

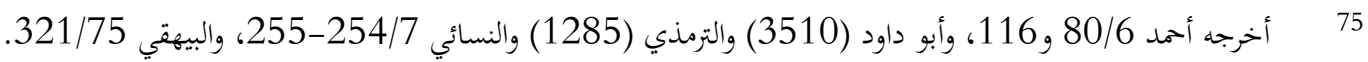

$$
\begin{aligned}
& 767 \text { } 77
\end{aligned}
$$

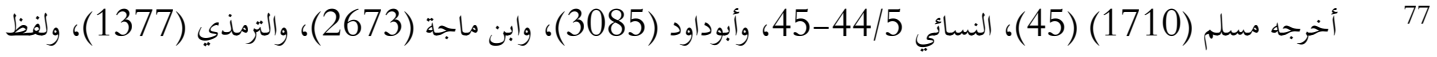

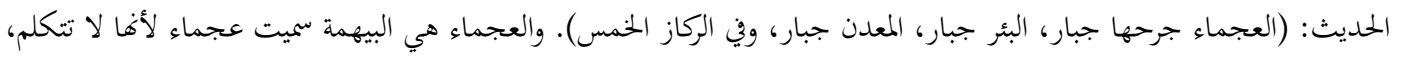

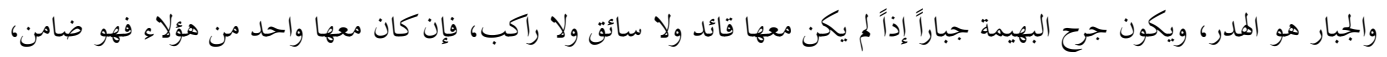

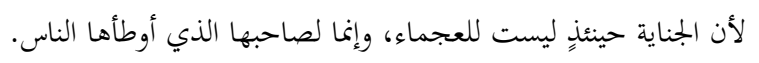


حكم، والقاعدة المقصدية تعبر عن غاية، وإن القواعد الفقهية ذاتحا لتنص بصراحة على أن (مراعاة المقاصد مقدمة عى الوسائل).

\section{رابعاً: من حيث الاختلاف والاتفاق على مضمونها:}

الدارس للقاعدة يجد أن هذه القواعد ليست على وزان واحد، من حيث اتفاق الفقهاء على ما تضمنته من حمك كلي، إذ إن القواعد الفقهية قسمان:

- قسم مُسلّم به، وهو محل اتفاق واعتبار من جميع الفقهاء، كالقواعد الكلية الخمس: (الأمور بمقاصدها)، و(اليقين لا يزول بالشك)، و(العادة محكمة)، و(الضروريات تبيح المخظورات)، و(المشقة بحلب التيسير)، وغيرها من القواعد الأخرى التي لم يجر اختلاف في اعتبارها والاعتداد بها مثل قاعدة (تصرفات الإمام علالرعية منوطة بالمصلحة) 79 و (درء المفاسد أولى من جلب المصالح).

- وقسم أخر من القواعد الفقهية هو موضوع اختلاف ونظر بين الفقهاء، فبعضهم اعتبرها وبنى عليها، وفرّع على أساسها، وآخرون ل لم يعتبروا مضموها، ولا الحكم الذي عبرت عنه، ومن ذلك مثلاً قاعدة (الأجر والضمان لا يجتمعان). 81

فالقواعد الفقهية ليست كلها محل اتفاق بين الفقهاء، لذا فإن الإمام الولشريسي 82 صاغ كثيراً من القواعد الفقهية على صيغة استفهام، مبيّناً أها ليست محل اتفاق بين الجميع، ومن ذلك مثلاً:

$$
\text { الموجود شرعاً هل هو كالموجود حقيقة؟83 }
$$

- إقلاب الأعيان هل له تأير في الأحكام أم لا؟84

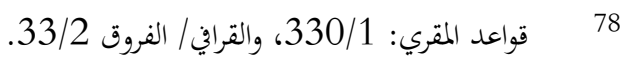

$$
\begin{aligned}
& 7970 \\
& 80 \text { 8 } \\
& \text { المسلك ص219. } \\
& 81 \\
& 82
\end{aligned}
$$

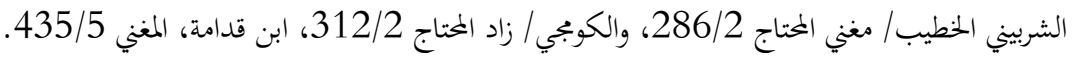




$$
\text { - - الظن هل ينقض بالظن أم لا؟85 - نوادر الصور هل يعطي لها حكم نفسها أو حكم غالبها؟87 }
$$

فهذه القواعد ليست محل اتفاق بين الفقهاء، مما حدا بالولشريسي أن يصوغها بصيغة الاستفهام، مبيّنًا ما يترتب عليها من اختلاف عملي. أما بالنسبة إلى القواعد المقصدية، فالإمام الشاطبي يقرر أن معاني القواعد لكثرة انتشار الجزئيات التي تتضمنها، وتأكيد تقررها في أبواب الشريعة المختلفة، هي من المكانة والاعتبار، مما يجعلها صوراً للنص العام سواء بسواء، من حيث إلزامية المجتهد باتباع مضموها، والالتزام بمعناه، ويصرح بذلك فيقول: (إذ صار ما استقري من عموم المعنى كالمنصوص بصيغة عامة، فكيف يحتاج مع ذلك إلى صورة خاصة بمطلوبه). 88 وإذا ما وجدنا أن بعض الفقهاء يخالف معنى إحدى هذه القواعد المقصدية في مسألة جزئية، فليس معنى ذلك أن ذاك الفقيه لا يعتبر تلك القاعدة في الاستدلال، وإنما يرجع الأمر إلى عدم تحقق مناطها وفق نظر ذاك الفقيه في الواقعية الجزئية ومن ذلك مثلاً: أن الشافعي - رضي الله عنه - قال بجواز بيع العينة، الذي هو عقد في صورة بيع لاستحلال الربا، لم يقل بجوازه إهمالاً منه لقاعدة (النظر في المآل معتبر مقصوداً شرعاً) 89 وإنما مرد ذلك وسببه أنه لا يرى مناط هذه القاعدة قد تحقق في تلك المسألة، أو أنه عرض له دليل آخر وجده أكثر لصوقاً بييع العينة وتناوله لها وكشفاً عن حكمها، من تلك القاعدة. 90

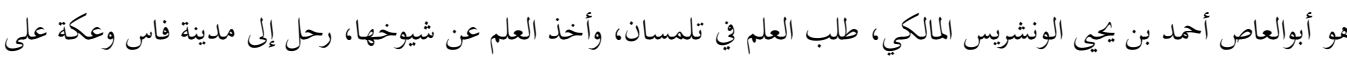
84

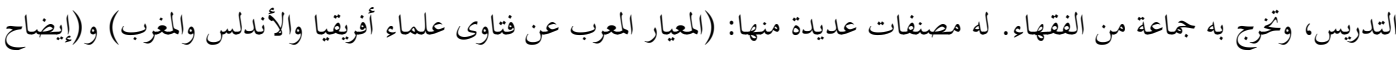

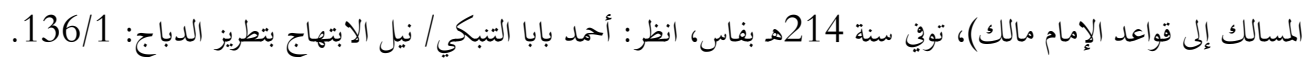
85 86 86 87 304/3 88 89 انظر رأي الشافعي مصحوباً بأدلته في (الأم) 201/3. 
إذن فهذه القواعد نظراً لكثرة تأكدها وانتشارها في أبواب الشريعة المختلفة، لا يسع الفقهاء والمجتهدون مخالفتها، أو إهمالها، أو عدم الاعتداد بها.

هذه هي الفروق التي لاحت لي بين القاعدة المقصدية من جهة، والقاعدة الفقهية من جهة أخرى. على أنه مما ينبغي الاشارة إليه: أن هنالك بعض القواعد الفقهية تُعد عند التحقيق قواعد مقصدية، كقاعدة (درء المفاسد مقدم على جلب المصالح) وقاعدة (إذا تعارضت مفسدتان قدمت أعظمهما بارتكاب أخفهما)، والقواعد التي توجب إزالة الضرر ورفعه مثل (لا ضرر ولا ضرار)، فهذه القواعد وإن كانت قد أدرجت ضمن القواعد الفقهية، إلا أها عند التحقيق ذات صبغة مقصدية، ذلك أها تكشف لنا عن قصد الشارع في كيفية إقامته للمصالح، واعتماده مبدأ الموازنة بينها عند التعارض، إضافة إلى كوها تستند إلى أدلة كثيرة ترشد إليها وتنهض بها، الأمر الذي يجعلها في رتبة العموم المعنوي الذي تمتاز به القاعدة المقصدية.

\section{الفرق بين القاعدة المقصدية والقاعدة الأصولية:}

يمكن تعريف القاعدة الأصولية: بأها قضية كلية يتوصل بها الفقيه إلى استباط الأحكام الشرعية من أدلتها التفصيلية. وهي بذلك تلتقي مع القاعدة المقصدية كون كلْي القاعدتين لا يقوم الاستباط والاجتهاد إلا بهما، إذ إن المجتهد لا بد أن يكون محيطاً بالقواعد المقصدية إحاطته بالقواعد الأصولية المعهودة، فلا يصح للمجتهد أن يطبق القواعد الأصولية المتعلقة بالأمر والنهي، والعام والخاص مثلاً، دون أن يلتفت إلى المقصد الشرعي من تلك الألفاظ أمرها وغيها، وعامها وخاصها.

وهذا ما يصرح به الإمام الشاطبي بقوله (لا بد من الالتفات لإلى معاني الأمر لا إلى مجرده) مقصود الأمر وغايته لا إلى مجرد صورته ولفظه.

ويظهر من خلال المقارنة بين طبيعة القاعدة المقصدية، وطبيعة القاعدة الأصولية، أن ثمة فروقاً يمكن

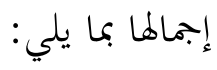




\section{أولاً: من حيث الحقيقة:}

إن من أنعم النظر في جل القواعد التي ساقها الأصوليون في كتبهم المختلفة، وجد أهما تختلف في

حقيقتها عن القواعد المقاصدية وبيان ذلك: أن هذه القواعد هي قواعد استدلالية، تدور في معظمها حول منهج الاستنباط والاستخراج للأحكام الشرعية من أدلتها التفصيلية، دون إشارة إلى الغاية التي تسعى تلك الأحكام لإقامتها في الواقع الإنساني ولا بيان منها للأهداف التشريعية العليا، التي يقصد الشارع إلى تشييدها عن طريق أحكامه، وهذا ظاهر بيّن في جل القواعد الأصوليّة مثل: (النهي يقتضي الفور والدوام)، 92 (النهي المطلق يفيد التحريم).

فالمجتهد إذا أخذ هذه القواعد الأصولية ليطبقها على النصوص كقوله تعالى:

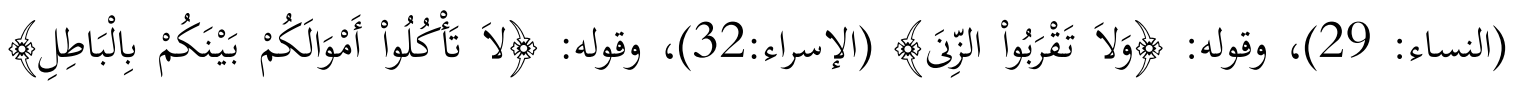

أفادت هذه النصوص بناء على تلك القواعد الأصولية، حرمة قتل النفس، وحرمة الإقتراب من الزنا، وحرمة أكل مال الغير بالباطل، كما تفيد بناء على قاعدة (النهي يقتضي الفور والدوام) وجوب الاستدامة على ترك هذه الخرمات، والمبادرة في الابتعاد عنها، ولا تعبر هذه القواعد عن الحكمة أو الغاية التي شرع من

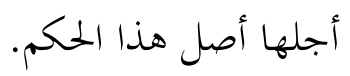

ولا نجد عند الأصوليين إلتفاتاً إلى هذه المعاني التشريعية، إلا عند بحثهم لموضوع القياس عامة وفي مبحث المناسبة خاصة. أما القاعدة المقصدية - وإن كانت ركناً من ركني عملية الاستنباط كما بينت آنفاً فإنها سبقت أصلاً لبيان هذه الحكم والمقاصد والغايات التي يستهدفها التشريع الاسلامي من خلال أحكامه، فإذا كانت القاعدة الأصولية وسيلة لتبيين الحكم الشرعي الذي خاطب به الله تعالى المكلفين، فإن القاعدة المقصدية هي التي تكشف عن الغية الكلية أو الجزئية التي ترسمها الشارع من وراء تشريعه، فأضحت

$$
92 \text { } 92 \text { صلفت الإشارة إلى هذه القاعدة. }
$$


القاعدة المقصدية بذلك وسيلة للكشف عن الحكم الشرعي والحكمة التشريعية لا الحكم فقط، كما هو الحال في جل القواعد الأصولية.

وهذا الملحظ هو ما أشار إليه الشيخ الطاهر بن عاشور حيث قال: "على أن معظم مسائل أصول الفقه لا ترجع إلى خدمة حكمة شرعية ومقصدها، ولكنها تدور حول محور استنباط الاحكام من ألفاظ الشارع بواسطة قواعد تمكن العارف بها من إنتزاع الفروع منها". 94

ثم يقول بأنه لا يسلم من ذلك إلا بعض المباحث في أصول الفقه، وهي نزرة قليلة: (ومن وراء ذلك خبايا في بعض مسائل أصول الفقه، أو في معمور أبوابها المهجورة عند المدارسة، ترسب في أواخر كتب الأصول التي لا يصل إليها المؤلفون إلا عن سأمة، ولا المتعلمون إلا الذين رزقوا الصبر على الإدامة وهذه هي مباحث المناسبة والاخالة في مسالك العلة، ومبحث المصالح المرسلة، ومبحث التواتر...). 95 على أن المعاني التي أشار إليها الأصوليون في بحثهم للمناسبة والمصالح المرسلة وغيرها من المباحث القليلة التي عبروا من خلالها عن معانٍ تشريعيّة تندرج عند التحقيق ضمن القواعد المقصدية التي بيّها الإمام الشاطبي وذكرها، وهي أكثر لصوقاً وأعظم صلة بالقواعد المقصدية التي نهن بصدد بيان حقيقتها، منها بالقواعد الأصولية التي فصلها الأصوليون، والتي تعتمد في الكثير الغالب منها على ما قرّره أئمة اللغة من أسلوب الخطاب العربي. - ماب.

\section{ثانيا: من حيث المضمون والموضوع:}

لما كانت القاعدة المقصدية مفاهيم تشريعيّة كلية التفت إليها الشارع، وراعاها في تشريعيه، تتضمن مواضيع لا تراعيها القاعدة الأصولية، فالقاعدة المقصدية مثلاً تبيّن العلة في كون بعض الأفعال، كانت أكثر طلباً وأشد إلزاماً من البعض الآخر. يبيّن الإمام الشاطبي الفلسفة التشريعية في شدة الطلب أمراً كان أو هيًا

$$
\begin{aligned}
& 94 \\
& 95
\end{aligned}
$$


فيقول: "المفهوم من وضع الشارع أن الطاعة والمعصية تعظم بحسب عظم المصلحة أو المفسدة الناشئة عنها".

فهو يبين السبب في كون بعض الأوامر أكثر إلزاماً وطلباً من بعض الأوامر الأخرى وأظهر الحكمة في

كون بعض النواهي أكثر زجراً وطلباً للكف عنها، وأن هذا عائد إلى ما يترتب على تلك الأفعال من مصلحة أو مفسدة، فكلما كانت مصلحة الفعل أعظم كان الطلب آكد، وكلما كامت المفسدة أعظم كان النهي أشد، إجراء للحكم على قدؤ الدليل.

هذه المعاني التشريعية التي تتضمنها القواعد المقصدية، والتي يعبر عن موضوعها الأساسي، لا نجدها في القاعدة الأصولية التي ينحصر موضوعها في الأدلة السمعية وكيفية استثمارها لإظهار الحكم الشرعي. 97 ثالثاً: من حيث المصدر:

يصرح الإمام القرافي بأن جل القواعد الأصولية مأخوذة من مقتضيات اللغة العربية وكيفية دلالتها على المعني من خلال الألفاظ فيقول: وأصول الشريعة قسمان:

- أحدهما: المسمى بأصول الفقه، وهو في غالب أمره ليس فيه إلا قواعد الأحكام الناشئة عن الألفاظ العربية خاصة، وما يعرض لتلك الألفاظ من النسخ، نهو الأمر للوجوب، والنهي للتحريم، والصيغة الخاصة للعموم، ونخو ذلك. وما خرج عن النمط إلا كون القياس حجة، وخبر الواحد وصفات المجتهدين.

- والثاني: قواعد كلية فقهية جليلة، كثيرة العدد، عظيمة المدد. 98

وهذا ما نطقت به عبارات أكثر الأصوليين في معرض بياغم للعلوم التي استمد منها علم أصول الفقه، ومن ذلك ما قاله الآمدي: (أما ما منه - أي علم الأصول - فعلم الكلام، والعربية، والأحكام الشرعية). 99

$$
\begin{aligned}
& 96 \\
& 97 \text { } 98 \\
& 98 \\
& 99 \text { } 99 \text { الآمدي/ الإحكام: 7/1، وانظر أيضاً الفتوحي/شرح الكوكب المنير: 48/1، وأبو حيان/ البحر الميط 28/1-29. }
\end{aligned}
$$


وهذا الأمر لا يتحقق في القاعدة المقصدية، فهي ليست مستمدة من حلالات الألفاظ بحسب أصل وضعها الغوي، ولا هي مقتنصة من مبادئ علم الكلام والمنطق، وإنما هي مستمدة ابتداء من تصفح جزئيات

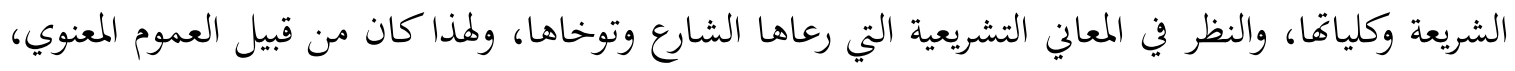
فجزئيات الشريعة وكلياتا هي التي مضت بالقاعدة المقصدية إلى رتبة الدليل العام المستقل. رابعاً: وفرق آخر بيين القاعدة المقصدية والقاعدة الأصولية ليست كلها محل اتفاق الأصوليين، وتبع هذا الاختلاف في حجية بعض القواعد الأصولية، اختلاف فيما ينشأ عنها من فروع فقهية. من ذلك مثلاً:

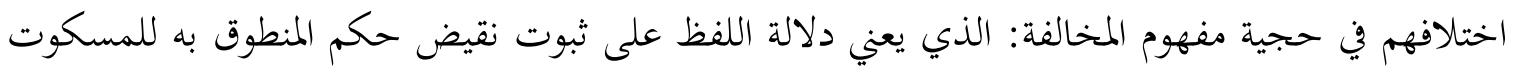

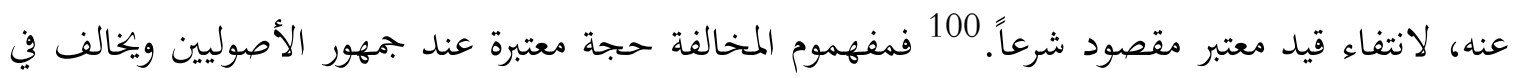

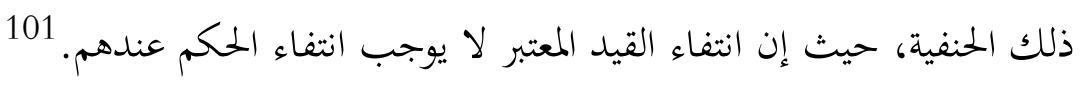
ومن هذه القواعد الأصولية أيضاً: الأمر المطلق هل يقتضي الفور؟

فأكثر أصحاب أبي حنيفة والشافعي قالوا: إن لا يقتضي الفعل المأمور به على الفور. 102 على حين ذهب بعض الحنفية وجمهور المالكية والحنابلة إلى الأمر المطلق للفور. 103 ومنها: دلالة العام على كل فرد من أفراده، حيث يقول الحنفية بقطعية دلالة العام على أفراده ما لم يخصص. 104

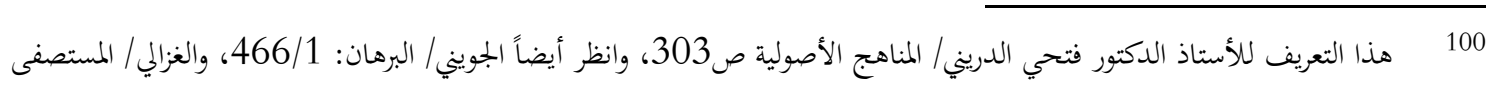

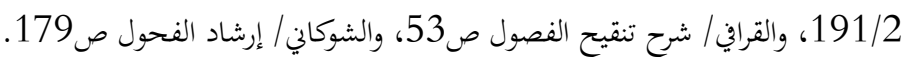

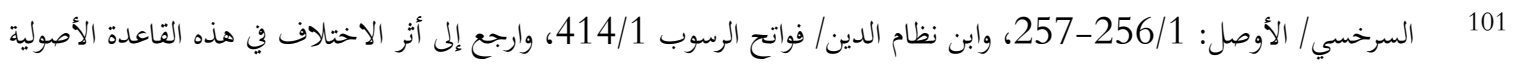

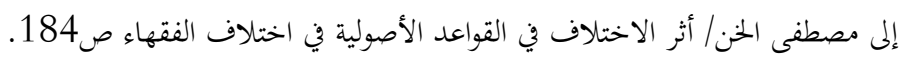

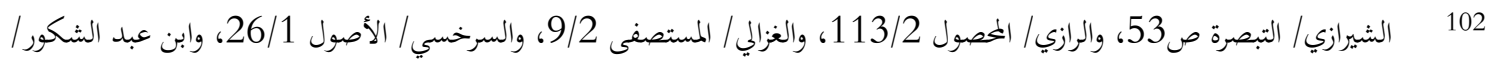

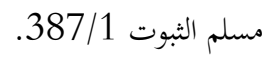
103 104 
في حين يقول جمهورالأصوليين من المالكية والشافعية والحنابلة بظنية دلالة العام على كل فرد من

$$
\text { أفراده } 105 \text { إلى غير ذلك من القواعد الأصولية الأخرى التي جرى الاختلاف عليها. }
$$

هذا بالنسبة إلى القاعدة الأصولية، أما القاعدة المقصدية التي تعبر عن معان عامة، فمن المفترض أن تكون موضوع إعتبار من الجميع، إذ إها في رتبة النص العام كما سبق تفصيل ذلك.

وعلى هذا، فإن القاعدة المقصدية ضربّ جديٌُّ من القواعد، يختلف في حقيقته ومصدره ومرتبته عن

كلتا القاعدتين الأصولية والفقهية، والأئمة والعلماء وإن كانوا قد أشاروا إلى بعض تلك القواعد من خلال مباحث معدودة في كتب القواعد والأصول فإفم لم يولوا هذه القواعد ما تستحقه من التأصيل والبيان والثفريع.

هذا ولا بد من الإشارة انتهاءً إلى أن القاعدة المقصدية وإن كانت تختلف عن القاعدة الأصولية، فلا يلزم من ذلك أن تكون قواعد المقاصد خارجة عن مضمار علم الفقه كعلم؛ ذلك أن علم الأصول ليس معرفة قواعد أصول الفقه فَحَسنب، بل هو كيفية استعمال هذه القواعد وتوظيفها. ومن لم يكن متمكناً من القواعد المقصدية، فلن يستطيع أن يوظف تلك القاعدة الأصولية على الوجه المطلوب، ومن هنا فإن القاعدة المقصدية تقف جنباً إلى جنب مع القاعدة الأصولية، حتى يتوصل المجتهد إلى الحكم الشرعي الذي أراده الشارع وابتغاه.

فالإمام الشاطبي إذاً يرتقي بالقاعدة الأصولية ليعطيها بعدها المقصدي، فلا تبقى محصورة في الجوانب اللغوية والأمور الكلامية، وإنما تتسع لتتصل بالتشريع ومعانيه الكلية.

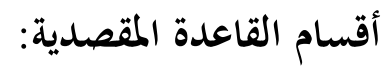

مما يزيد القاعدة المقصدية جلاءً ووضوحاً: النظر في الأسس والاعتبارات التي يمكن أن تشكل معالم أساسية لتقسيم القواعد المقصدية ضمن فئات مختلفة

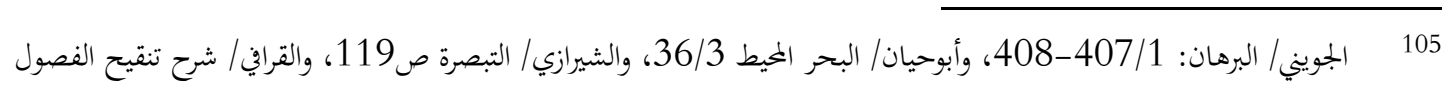

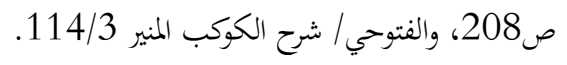


ومنظومات متعددة ومتنوعة، ويمكن أن أسجل أبرز هذه المعالم على أنه يمكن الاجتهاد في إظهار معالم أخرى تكون أساساً في التقسيم والتوزيع:

أولاً: الموضوع الذي تضمنته القاعدة المقصدية وتعبر عنه، فالقاعدة تختلف باختلاف موضوعها المباشر، الذي سبقت لبيانه وتوضيحه.

ثانياً: عموم القاعدة وخصوصها، فالقاعدة ليست كلها على وزن واحد من حيث العموم والخصوص، حيث نجد بعضها عاماً بحيث يمكن أن يستوعب غيره من القواعد أو تتفرع عنه، وبعضها الآخر أخص بحيث يتفرع عن قاعدة أوسع أو يندرج فيها.

ثالثاً: صاحب القصد، فإن القواعد المقصدية منها ما جاء ليحدد قصد الشارع من التشريع، ومنها ما سبق لوجه قصد المكلف، ليكون متوافقاً مع ما قصد الشارع، فصاحب القصد وفق ما تدل عليه القواعد، إما أن يكون الشارع، وإمّا أن يكون المكلف.

$$
\begin{aligned}
& \text { وأبين ذلك باختصار فيما يلي: } \\
& \text { أولا: من حيث المضمون: }
\end{aligned}
$$

القواعد المقاصدية وإن كانت تتفق جميعها من حيث الموضوع العام الذي ينتظمها جميعها، والمتمثل في الغاية التشريعية التي توجهت إرادة الشارع لإقامتها عن طريق أحكامه، والمعاني العامة التي استهدفها الشارع من تشريعه، أقول: هذه القواعد وإن كانت متفقة من حيث الموضوع العام، فهي مختلفة من حيث الموضوع المباشر الذي تضمنته كل الك القواعد.

ومن خلال دراستي لتك القواعد، استطعت - بعد النظر والتأمل - أن أحدد المواضيع التالية، كموضوع مباشرة تعبر عنها القواعد المقاصدية. 1) قواعد تتعلق بموضوع المصلحة والمفسدة: 
من حيث إن هذه القواعد تتحدد في تناولما لموضوع المصلحة والمفسدة، إلا أها تختلف في كيفية تناولها لهذا الموضوع، فبعضها يبين الأساس العام الذي قامت عليه الشريعة كلها في جزئياها وكلياها، المتمثل في جلب المصالح ودرء النفاسد، ومن هذه القواعد على سبيل المثال لا الحصر:

$$
\begin{aligned}
& \text { (وضع الشرائع إنما هو لمصالح العباد في العاجل والآجل معاً). } 106 \\
& \text { (الأمر في المصالح مطرد مطلقاً في كليات الشريعة وجزئياتا). } 107 \\
& \text { (التكليف كله إما لدء المفاسد أو لجلب المصالح أو لهما معاً). } 108
\end{aligned}
$$

(الأسباب الممنوعة أسباب للمفاسد لا للمصالح، والأسباب المشروعة أسباب للمصالح لا للمغاسد).

(المفهوم من وضع الشارع، أن الطاعة أو المعصية تعظم بحسب عظم المصلحة أو المفسدة الناشئة عنها). وهناك قواعد تكشف عن وجه العلاقة بين مراتب المصلحة الثلاث: (كل حاجي وتحسيني إنما هو خادم للأصل الضروري ومؤنس بع، ومحسن لصورته الخناصة). 111 (إن مجموعة الحاجيات والتحسينيات، ينتهض أن يكون كل واحد منهما كفرد من أفراد الضروريات).

$$
\begin{aligned}
& 106 \\
& 107 \\
& 108 \\
& 109 \\
& 110 \\
& 111 \\
& 112
\end{aligned}
$$


إلى غيرها من القواعد الأخرى، التي تظهر صلة كل واحد من المراتب الثلاث بغيرها من المراتب

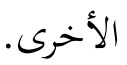

وهناك قواعد تظهر دور الجُتهد في الالتفات إلى المعنى المصلحي الذي سبق الحكم من أجله، وإلى

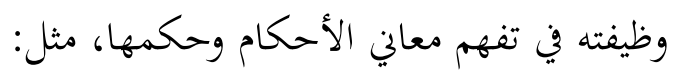
(لا بد من الالتفات إلى معاني الأمر لا إلى مجرده). (العمل بالظواهر على تتبع وتغال بعيد عن مقصود الشارع، كما أن إهماما إسراف أيضا). 114 فهذه القواعد تتعلق بدور المجتهد في إدراك معاني الأحكام وغاياتما المصلحية، فجميع هذه القواعد تتناول موضوع المصلحة، وإن اختلفت كيفية تناولها لهذا الموضوع.

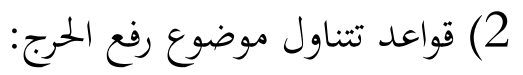
وهناك قواعد مقاصدية تدور في فلك رفع الحرج زما ينبثق عنه من قضايا وتفريعات، والكشف عن

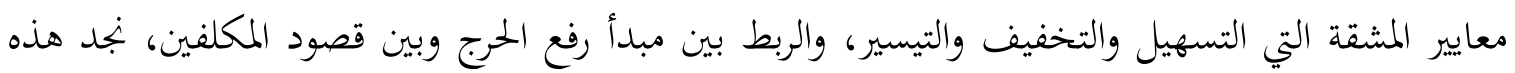
المعالم واضحة حين ننعم النظر في القواعد التالية:

$$
\text { (الشارع لم يقصد التكليف بالشاق والاعنات فيه). }
$$

(الشريعة جارية في التكليف بعتضاها، على الطريق الوسط الأعدل الآخذ من الطرفين بقسط لا ميل فيه، الداخل تحت كسب العبد من غير مشقة عليه ولا انحلال).115 فهذه القواعد وغيرها كثير، تبين أن قصد الشارع لا يتوجه إلى خطاب المكلفين بما لا قدرة لمم عليه، أو ما لا يملكون القيام به إلا بمشقة بالغة غير معتادة.

114 113 المرجع السابق.


ثم يبين الإمام الشاطبي من خلال القواعد أيضاً، ضوابط المشقة وحدودها التي تستوجب التيسير، ومن ذلك مثلاً: (إذا كانت المشقة خارجة عن المعتاد، بحيث يكصل للمكلف فيها فساد ديني أو دنيوي، فمقصود

$$
\text { الشارع فيها الرفع على الجملة). } 116
$$

فالإمام الشاطبي في هذه القاعدة، يسبن المشقة التي تُعد شرعاً، وهي التي فيها خروج عن المعتاد من الأعمال، بحيث يشوش على النفوس تصرفها، ويقلقها بما فيه من تلك المشقة.

على ذلك فإن المشاق المعتادة التي تكون ملازمة للعمل، بحيث لا تنفك عنه، وأضحت بمثابة الجزء المصاحب له، لا تُعد مشقة تستلزم التخفيف والتيسير.

ويؤكد الإمام الشاطبي هذا المعنى ويوثقه، حيث يأتي بقاعدة من هذا القبيل ينص فيها: (مشقة مخالفة

$$
\text { الموى، ايست من المشاق المعتبرة، ولا رخصة فيها البتة). } 117
$$

وعدم اعتبار مشقة مخالفة الهوى، راجع إلى أنه لا يقوم التكليف أصلاً إلا بمخالفة أهواء النفوس، فإذا اعتبرت هذه الأهواء في التخفيف، كان ذلك داعياً إلى إسقاط التكيف عنه. 3) قواعد تتعلق بمآلات الأفعال ومقاصد المكلفين:

كذلك فإنني وجدت بعد التتبع والدراسة، أن بعض القواعد ينتظمها موضوع مقاصد المكلفين ومآلات تصرفاتم، والقواعد في هذا الموضوع كثيرة:

منها قواعد تتعلق بوجوب النظر إلى المآل وضرورة اعتباره، نظراً لمراعاة الشارع له، من ذلك: (النظر في المآل معتبر مقصوده شرعاً). 118 (وينبعي على المجتهدين أن ينظروا إلى مسببات الأحكام وأسباباها لما يترتب

\begin{tabular}{|c|c|}
\hline المرجع السابق & \\
\hline لرجع السابق. & \\
\hline لرجع السابق. & \\
\hline 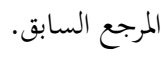 & \\
\hline
\end{tabular}
على ذلك من الأحكام الشرعية). 
وقواعد أخرى تتعلق بتوجيه مقاصد المكلفين، بحيث تكون متوافقة مع قصد الشارع مثل:

(قصد الشارع من المكلف أن يكون قصده في العمل، موافقاً لقصده في التشريع، وإلا يقصد خلاف

ما قصد).

$$
\text { (المقاصد معتبرة في النصرفات). } 121
$$

(إذا كان الالتفات إلى المسبب من شأنه التفويه للسبب والتكملة له، والتحرض على المبالغة في

$$
\text { إكماله، فيجب الالتفات إليه). }
$$

ويندرج تحت هذه القواعد أيضاً، القواعد التي تظهر أثر مناقضة المكلفين في تصرفاقم لقصد الشارع،

سواء أكان منشأ تلك المناقضة قصد المكلف، بحيث توجهت إرادة المكلف إلى نقيض ما قصد الشارع، أم كان منشؤها - أي المنقضة - مآل التصرف، من غير سبق قصد لتلك المناقضة.

ومن هذه القواعد أيضاً: (كل من ابتغى في التكاليف الشرعية غير ما شرعت له فقد ناقض الشريعة).

(إن كان فعل الشرط أو تركه قصداً لاسقاط حكم الاقتضاء في السبب، ألا يترتب عليه أثره، فهذا عمل غير صحيح، وسعي باطل). 122 (من سلك إلى مصلحة غير طريقها المشروع فهو ساعٍ في ضد تلك رك 123.

(كل فعل مشروع يصبح غير مشروع إذا أدى إلى مآل ممنوع، قصد المكلف ذاك المآل أم لم يقصد).

هذه هي الموضوعات الأساسية التي تتناولها القواعد المقاصدية بالبيان والتفصيل، وفق ما ظهر لي بعد البحث والنظر.

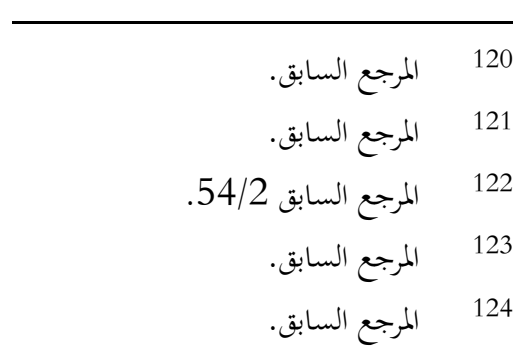


على أنه تنبغي الإشارة، إلى أن هذه المواضيع وإن كان كل منها قائماً بذاته يشمل قواعده ومباحثه المستقلة، فإن أي موضوع من هذه الموضوعات ليس مبتوراً على غيره من الموضوعات الأخرى، التي سيقت القواعد المقاصدية لتفصيلها وتأصيلها، فموضوع المصلحة والمفسدة من الشمول والسعة، بحيث يمكن أن يندرج تحته موضوعا مآلات الأفعال ورفع الحرج، إذ إن رفع الحرج ما كان إلا تحقيقاً لمصالح العباد، ودفعاً للمفسدة عنهم.

وكذلك فإن موضوعات مآلات الأفعال، وما يندرج تحته من قواعد بمقاصد المكلفين، تبقى الصلة بموضوع المصلحة والمفسدة، ذلك بأن القواعد التي توجب النظر إلى المآل، إنما توجب مراعاة المصالح التي قصد الشارع إقامتها من الحكم، فإذا وجد المجتهد أن الحكم الأصلي ما عاد يحقق في مآله مصلحته المقصودة، نظراً لما احتف به من قرائن ووقائع، وجب أن يراعى ذاك المآل، حفاظاً على المصلحة المقصودة من الحكم.

كذلك فإن توجيه مقاصد المكلفين، لتكون متوافقة مع قصد الشارع، هو موضوع وثيق الصلة بموضوع المصلحة، إذ إن هذا التوجيه لمقاصد المكلفين، ما كان إلا حفاظاً على مصلحة الحكمم من أن تنقض أن هدر وهذه الصلة عبرت عنها القواعد المقاصدية نفسها، مثل: (خخافة قصد الشارع، هدم لأساس المشروعات القائمة على إقامة المصالح ودرء المفاسد). 125

وكما يرتبط كل من موضوعي رفع الحرج ومآلات الأفعال بموضوع المصلحة، فإن كلا من موضوع رفع الحرج، ومآلات الأفعال يتصل بالآخر أيضاً. ولقد عكست القواعد المقاصدية هذه الصلة، من ذلك مثلاً، القاعدة التي ساقها الشاطبي في معرض بيانه للمشقه المعتبرة التي تستوجب التيسير حيث قال: (إذا كانت المشقة خارجة عن المعتاد، بحيث يكصل بها للمكلف فساد ديني أو دنيوي فمقصود الشارع فيها الرفع على الجملة).

$$
126 \text { 1 } 125
$$


حيث حكم الشاطبي على المشقة بأها مشقة، من خلال مآلما ونتيجتها، وهو ما يلحق بسببها من فساد ديني أو دنيوي.

ومن هذه القواعد أيضاً (ليس للمكلف أن يقصد المشقة نظراً إلى عظم أجرها، وله أن يقصد العمل

$$
\text { الذي يعظم أجره لعظم مشقته، من حيث هو عمل). }
$$

والقاعدة: (إذا فعل المكلف المانع قصداً لاسقاط حكم السبب المقتضي أن لا يترتب عليه ما اقتضاه،

$$
\text { فهو عمل غير صحيح). }
$$

فهذه القواعد تفريع على الأصل العام الذي يشترط التوافق والتآلف بين قصد المكلف من التصرف

$$
\text { مع قصد الشارع من التشريع. }
$$

وهكذا نجد أن العموم في القواعد المقاصدية ليس على وزان واحد، بل هو عمومان: (عموم أعم، وعموم أخص ينبثق عن الأعم، والعموم الأخص، إما أن يكون ضابطاً للأصل الكلي، أو مفصلاً وموضحاً

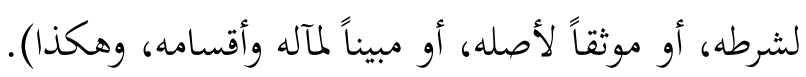

\section{ثالثا: القاعدة المقصدية من حيث صاحب القصد:}

والمحمور الثالث الذي يُعد أساساً في التفريق بين القواعد المقاصدية، وهو صاحب القصد، ذلك أنه بالنظر في قواعد المقاصد، نجد أن بعض القواعد جاءت تبياناً لقصد الشارع من التشريع، وبعضها الآخر جاء توجيهاً وإرشاداً للمكلف في قصده.

ولقد أشار الإمام الشاطبي في مقدمة بيانه لمقاصد الشريعة، إلى أن المقاصد تنقسم إلى قسمين:

$$
\text { أحدهما يرجع إلى قصد الشارع. }
$$

$$
\text { والآخر يرجع إلى قصد المكلف. } 128
$$

$$
128 \text { المرجع السابق. }
$$


فإذا كانت المقاصد تنقسم إلى هذين القسمين، وفق بيان الإمام الشاطبي، فإن من اللازم أن تكون القواعد التي تضبط هذه المقاصد، جارية على وفق هذا النسق، من حيث النظر إليها وفق هذين الاعتبارين، قصد الشراع أو قصد المكلف.

ويظهر هذا بيناً في القواعد المقاصدية، ففي معرض بيان قصد الشارع جاء كثير من القواعد مثل: (المقاصد العامة للتعبد هي الانقياد لأوامر الله تعالى، وإفراده بالخضوع والتعظيم لجلاله والتوجه إليه). 129 (اجتناب النواهي، آكد وأباغ في القصد الشرعي من فعل الأوامر، ودرء المفاسد أولى من جلب المصالح).

(وضعت الشريعة على أن تكون أهواء العباد تابعة لمقصود الشارع فيها، وقد وسّع الله على العباد في شهواقم وتنعماقم بما بكفيهم). 131 (من مقصود الشارع في الأعمال دوام المكلف عليها). 132 (النظر في المآل معتبر مقصود شرعاً). 133

(لا نزاع في أن الشارع قاصد إلى التكليف بما يلزم فيه كلفة ومشقة ما، ولكنه لا يقصد نفس المشقة، بل يقصد ما في ذلك من المصالح العائدة على المكلف). فهذه القاعدة وإن كانت من قواعد موضوع رفع الحرج، إلا أها متصلة بالقواعد التي سيقت لتوجيه قصود المكلفين لتكون منسجمة مع قصد الشارع، متوافقة مع إرادته.

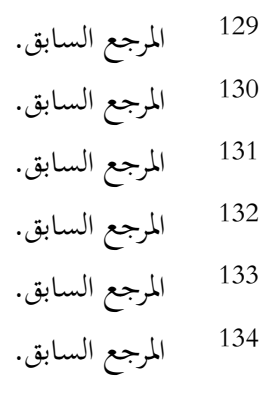


وهكذا يجد الباحث أن الاتصال الوثيق بين هذه الموضوعات الثلاثة، يحتم التلاقي بين قواعد هاتيك

الموضوعات، ويؤكد الصلة بينها.

ثانياً: القاعدة المقصدية من حيث الكلية والعموم:

القواعد المقصدية، وإن تحقق في جميعها وصف العموم والكلية، إلا أن عمومها وكليتها ليسا على وزن

واحد، فهناك قواعد هي من الكلية والعموم، بحث يمكن اعتبارها أصولاً لقواعد مقصدية أخرى تتفرع عليها،

وتنبثق عنها.

وهناك قواعد أخرى، رغم كليتها وعمومها، نجدها منضوية تحت لواء قاعدة أخرى أكثر عموماً

واتساعاً كلية وبيان ذلك وتفصيله يظهر فيما يلي:

فالقاعدة المقصدية (مقاصد الشارع في بث المصالح في التشريع أن تكون مطلقة عامة، لا تختص في باب دون باب، ولا بمحل دون محل)، 135 والقاعدة (الأمر في المصالح مطرد مطلقاً في كليات الشريعة

وجزئياها)، 136 تبينان ابتناء الشريعة على أساس جلب المصالح ودرء المفاسد في الكليات والجزئيات، وتعتبر أصولاً لغيرها من القواعد الأخرى التي تنبثق عن هذه الحقيقة المستقرة، ومن هذه القواعد المتفرعة عنها:

القواعد التي سيقت لبيان حد المصالح يَعُدها الشارع من مثل: (وضع الشريعة وإن كان لمصالح العباد، فإنما هو حسب أمر الشارع، وعلى الحد الذي حده، ولا على مقتضى أهوائهم وشهواتم).

كذلك فإن القواعد المتعلقة بالضروريات والحاجيات والتحسينات تُعَد أصولاً لغيرها من القواعد الأخرى، إذ إن هذه المراتب الثلاث، هي من الشمول والاتساع، بحيث تصلح لاستعاب غيرها من القواعد المقاصدية. 
ولقد أشار الشاطبي إلى ذلك بقوله: "إذ ليس فوق هذه الكليات كلي تنتهي إليه، بل هي أصول

كذلك الأمر عندما نلتفت إلى القواعد المقاصدية التي تتعلق بقواعد المكلفين ومآلات تصرفاتم،

حيث نجد عند التحقيق والتدقيق، أن هناك قواعد أكثر كلية وعموماً من غيرها من القواعد مثل: (إنما الأعمال بالنيات، والمقاصد معتبرة في التصرفات من العبادات والعادات). 138

فهذه القاعدة التي تبين أن للقصد الذي تتوجه إليه إرادة المكلف اعتباراً وأثراً في الاعتداد بالتصرف الصادر عن المكلف، تُعَد أصلاً لغيرها من القواعد الأخرى التي تبين كيفية توجيه قصد المكلف حيث يكون صحيحاً معتبراً مم مثل: (قصد الشارع من المكلف، أن يكون قصده من العمل، موافقاً لقصده من التشريع، وإلا يقصد خلاف ما قصد). 139

كما أن هذه القاعدة تُعَد أصلاً لغيرها من القواعد الأخرى مثل: (إن كان فعل الشرط، أو تركه، قصداً لإسقاط حكم الاقتضاء في السبب أن لا يترتب عليه أثره فهذا عمل غير صحيح وسعي باطل). 140 فهذه القواعد كلها كما هو ظاهر منها، متعلقة ببيان قصد الشراع وعاياته، حتى يتبنها المكلف، فلا يأتي بما يناقضها، أو يكافحها صراحة. ومن القواعد التي جاءت توجيهاً للمكلف في قصده وباعثه: (من سلك إلى مصلحة غير طريقها المشروع، فهو ساعٍ في ضد تلك المصلحة). 141 (القصد إلى المشقة باطل، لأنه مخالف لقصد الشارع، ولأن الله لم يجعل تعذيب النفوس سبباً للتقرب إليه، ولا لنيل ما عنده). 142

\begin{tabular}{|c|c|}
\hline المرجع السابق & \\
\hline المرجع السابق & \\
\hline المرجع السابق & \\
\hline المرجع السابق & \\
\hline لمرجع السابق & \\
\hline
\end{tabular}


(ليس للمكلف أن يقصد المشقة نظراً إلى عظم أجرها، وله أن يقصد العمل الذي يعظم أجره لعظم مشقته، من حيث هو عمل). فكل هذه القواعد جاءت توجيهاً لقصد المكلف وإصلاحاً لباعثه، حتى لا يؤثر فساد القصد على صحة التصرف، وحتى يكون موافقاً لإرادة الشارع في الظاهر والباطن. وبذلك فإننا نلحظ البعد الواقعي لهذه القواعد، فحتى لا تبقى القواعد المبينة لقصد الشارع محلقة في سماء التنظير البعيد عن الواقع، ربطت بجانبها العملي عن طريق القواعد التي توجه قصد المكلف، إذ أن المحافظة على مقاصد التشريع لا تتأتى إلا بما أشار إليه الإمام الشاطبي من آليات تحقق ذلك، وتتم هذه المحافظة بأن يتوجه المكلف في قصده إلى تحقيق قصد الشارع في كل حكم عملي ليتم التطابق بينهما بأقصى جهد مستطاع، فلا ينبو قصد المكلف عن قصد الشارع.

وفي هذا تفعيل لمقاصد الشريعة، من حيث إنزالها من أفقها النظري إلى جانبها العملي في الواقع والحياة، عن طريف أفعال المكلفين ومقاصدهم، ليكون المكلف بعد تحقيق هذا التوافق عبداً لله اختياراً كما هو عبد له اضطراراً.

النتائج والتوصيات

بعد أن انتهيت في المطالب السابقة من بيان حقيقة القاعدة المقصدية، وأهميتها، ومكانتها من التشريع، والفرق بينها وبين القاعدة الفقهية والقاعدة الأصولية، فإني أضع أبرز النتائج والتوصيات.

أولا: للقواعد المقصدية تميز واستقلال عن كلٍ من القواعد الأصولية والفقهية، من حيث الحقيقة والحجية والمضمون. وهذا يعني أننا أمما شكل جديد وضرب فريد من أشكال البحث في علم القواعد يختص بتلك التي تبحث في المعاني التشريعية العامة. 
ثانياً: إن منشأ الزلل في بعض الاجتهادات المعاصرة يعود إلى عدم مراعاة الكليات التشريعية عند دراسة النصوص، والاكتفاء بتحكيم القواعد الأصولية وحدها، دون أن يقترن بذلك النظر إلى المعاني التشريعية، التي تُعَد قطب رحى الشريعة، إذ لا يصح دراسة الجزئيات بمنأى عن الكليات التي توجه الجزئيات وتضبطها.

ثالثاً: اعتمد السبقون من العلماء كثيراً من القواعد المقصدية في سبيل الحكم الشرعي، واعتبروا تلك القواعد بمثابة أدلة مستقلة ممكن أن يستند عليها لتأييد الحكم. رابعأ: القواعد المقصدية وإن كانت مختلفة عن القواعد الفقهية والأصولية حقيقةً ومضموناً، فإنها تلتقي معها في غاية واحدة وهي اسعاف المجتهد بالقواعد العامة التي يتحتم مراعاتما والاحاطة بها عند إرادة الكشف عن الحكم الشرعي في القضايا المختلفة.

خامساً: أدعو إلى مزيد من البحث والدراسة لموضوع قواعد المقاصد، حتى يغدو مبحثاً خاصاً من مباحث علم مقاصد الشريعة الإسلامية، يجري البحث فيه على نسق البحث في القواعد الفقهية والقواعد الأصولية.

وهذا يتطلب دراسة الكتب المقاصدية دراسة متأنية ومعمقة ككتاب (الفروق للقرافي) وقاعدة الأحكام للعز بن عبد السلام، وكتب الامامين المجددين ابن تيمية واين القيم، وقبل ذلك ما قدمه الإمام الجويني والغزالي في كتبهما المختلفة، بغية اقتناص القواعد المقاصدية المبثوثة في ثنايا تلك الكتب القيمة. سادساً: أوصي بدراسة قواعد المقاصد دراسة تحليلية تأصيلية بحيث يعم بيان حقيقة كل قاعدة على حدة، وإظهار أدلتها التي تستند إليها من موارد الشريعة المختلفة، والكشف عمّا ينبثق عن تلك القاعدة من قواعد وأصول، إضافة إلى ضرورة تفعيل تلك القواعد بالصور التطبيقية والوقائع والمسائل العملية, حتى يظهر أن هذه القواعد ليست قواعد محلّقة في سماء التنظير و وإنما هي قواعد ذات بعد عملي وفقه واقعي. سابعاً: أوصي الباحثين والدارسين المعاصرين في علوم الشريعة بضرورة تقديم الدراسات والأبحاث التي تميل إلى ضبط علم المقاصد من خلال قواعد محددة، تقدم لوناً جديداً من الدراسة في علم القواعد وعلم 
المقاصد، وأذكر بعبارة الإمام الزركشي - رحمه الله - (فإن ضبط الأمور المنتشرة المتعددة في القوانين المتحدة أوعى لحفظها وأدعى لضبطها). 